\title{
AN ADAPTIVE NONLINEAR LEAST-SQUARES
}

\section{ALGORITHM}

\author{
John E. Dennis, Jr.*, David M. Gay**, \\ and Roy E. Welscht
}

\section{TR77-321}

Revised July 1979

*Cornell University. Research supported in part by NSF Grant MCS76-00324

**NBER Computer Research Center Research supported in part by NSF Grant MCS76-00324 NSF Grant MCS78-09525

United States Army Contract DAAG29-75-C-0024

tMassachusetts Institute of Technology. Research supported in part by NSF Grants SOC76-14311 and MCS76-00324 


\section{$\underline{\text { ABSTRACT }}$}

NL2SOL is a modular program for solving nonlinear leastsquares problems that incorporates a number of novel features. It maintains a secant approximation $S$ to the second-order part of the least-squares Hessian and adaptively decides when to use this approximation. $\mathrm{S}$ is "sized" before updating, something which is similar to Oren-Luenberger scaling. The step choice algorithm is based on minimizing a local quadratic model of the sum of squares function constrained to an elliptical trust region centered at the current approximate minimizer. This is accomplished using ideas discussed by Moré, together with a special module for assessing the quality of the step thus computed. These and other ideas behind NL2SOL are discussed and its evolution and current implementation are also described briefly. 
AN ADAPTIVE NOHLINEAR LEAST-SQUARES ALGORITHM

by

J.E. Dennis, Jr., David M. Gay, Roy E. Welsch

\section{Introduction}

This project began in order to meet a need at the Computer Research Center of the National Bureau of Economic Research for a nonlinear least-squares algorithm which, in the large residual case, would be more reliable than the Gauss-Newton or LevenbergMarquardt method [Dennis, 1977] and more efficient than the secant or variable metric algorithms [Dennis $\varepsilon$ Moré, 1977] such as the Davicon-Fletcher-Powell, which are intended for general furction minimization.

We have developed a satisfactory computer program called :IL2SOL based on ideas in [Dennis $\varepsilon$ Welsch, 1976] and our primary purpose here is to report the details and to give some test results. On the other hand, we learned so much during the development which seems likely to be applicabie in the development of other algorithms that we have chosen to expand our exposition to include this experience.

In section 2 we will set out the problem and the notation we interd to use. Section 3 will deal with our way of supplementing the classical Gauss-Newton approximation to the least-squares Hessian by various analogs of the Davidon-Fletcher-Powell method. section 4 will briefly describe our interpretation of the orenLienturäs [Oren, 1973] sizing strategy for this augmentation. In section $S$ we describe our adaptive quadratic modeling of the objective function. Section 6 contains a discussion of the linear alsebra involved in extracting information from the quadratic models and section 7 contains test results. The NL2SOL Usage Suriary is included as an appendix. 


\section{The Nonlinear Least-Squares Problem}

There are good reasons for numerical analysts to study this problem. In the first place, it is a computation of priaday izportance in statistical data analysis and hence in the social sciences, as well as in the more traditional areas within the physical sciences. Thus a computer algorithm able to ded efficiently with both sorts of data is widely applicabie.

Although applicability should always constitute sufficient fustification to tackle a problem, in this case there is also an opportunity for more far reaching progress in numerical opii=ization. In order to be more specific, it will be useful to have a formal statement of the nonlinear least-squares problen.

We adopt notation consistent with fitting a model to $n$ pieces of data using $P$ parameters: Given $R: \mathbb{R}^{P} \rightarrow \mathbb{R}^{n}$, we wish to solve the unconstrained minimization problem

$$
\min f(x)=\frac{1}{2} R(x)^{T} R(x)=\sum_{i=1}^{n} \sum_{i}^{n} r_{i}(x)^{2}
$$

Notice that for $J(x)=R^{\prime}(x)=\left(\partial_{j} x_{i}(x)\right)$, the gradient of $f$ is:

$$
\nabla f(x)=J(x)^{T} R(x)
$$

and the Hessian of $f$ is:

$$
\nabla^{2} f(x)=J(x)^{T} J(x)+\sum_{i=1}^{n} r_{i}(x) \nabla^{2} r_{i}(x) \ldots
$$

Since we are seeking a minimum of $f$, we would wish to rave 
near zero, we will be forced to terminate on small parameter changes or to use some otber convergence criteria (see section 6). It is clear from (2.2) thet $\nabla f\left(x^{*}\right)=0$ and $R\left(x^{*}\right) \neq 0$ corresponds to $R\left(x^{*}\right) \perp C\left(J\left(x^{*}\right)\right)$, the colizan space of $J\left(x^{*}\right)$. Thus it is essential as the 1teration proceeds that $C\left(J\left(x_{k}\right)\right)$ be approximated very vell in the usual case where $p<n$ and $R\left(x^{*}\right) \neq 0$.

In adjition to making a preclse convergence test possible, having an accurate Jacobian matrix means that a good approximation to a portion of the Ressian is arallable as a byproduct of the gradient computation. In fact, it is often possible to ignore the second order term $\sum r_{1}(x) \nabla^{2} r_{1}(x)$ of the Fessian altogether on the grounds that if the nonzero residuals are not of a sort that reinforce thelr nonlinearity, $J(x)^{T} J(x)$ is a sufficlently good Eessian approxiration [Wedin, 1972, 1974a-c], [Dennis, 1977]. In the resulting Geuss-revton method, the "newton step" from $x_{k}$ 1. defined by the linear system of equations

$$
J\left(x_{k}\right)^{T} J\left(x_{k}\right)_{k}=-J\left(x_{k}\right)^{T} R\left(x_{k}\right) .
$$

Since (2.4) is the system of normal equations for the linear leastsquares problem

$$
\min _{8} \frac{1}{2}\left(J\left(x_{k}\right) s+R\left(x_{k}\right)\right)^{T}\left(J\left(x_{k}\right)_{s}+R\left(x_{k}\right)\right)
$$

1t 1s better to obtain $s_{k}$ from a QR decomposition of $J\left(x_{k}\right)$ (see [Golub, 1969]). We can viev (2.5) as defining a quadratic model in $x=x_{1}+$ or the least-squares criterion function (2.1): 


$$
\begin{aligned}
q_{k}^{G}(x)= & \frac{1}{2} R\left(x_{k}\right)^{T} R\left(x_{k}\right)+\left(x-x_{k}\right)^{T} J\left(x_{k}\right)^{T} R\left(x_{k}\right) \\
& +\frac{1}{2}\left(x-x_{k}\right)^{T} J\left(x_{k}\right)^{T} J\left(x_{k}\right)\left(x-x_{k}\right) .
\end{aligned}
$$

From (2.1), (2.2), (2.3) we see that the difference between this GaussNewton model and the usual Newton model obtained from a quadratic Taylor expansion around $x_{k}$ is just the term $z_{2}\left(x-x_{k}\right)^{T}\left[\sum_{1} r_{1}\left(x_{k}\right) \nabla^{2} r_{1}\left(x_{k}\right)\right]\left(x-x_{k}\right)$.

The conceptual difference between these two models is interesting in that it exposes some reasons for the deficlencies of the Gauss-lievton algorlthm. The Newton model 1s based on the assumption that $f$ can be adequately modeled by a quadratic, while the Gauss-Meuton model (2.6) is shown by $(2.5)$ to result from the stronger assumption that $R$ can be adequately modeled by an affine runction.

\section{An Augmentation of the Gauss-Newton Hessian.}

Our purpose in this section is to suggest a vay to augment the GaussNewton model (2.6) by adding an approximation to the difference between it and the quadratic Taylor expansion to obtain

$$
\begin{aligned}
q_{k}^{S}(x)= & \sum_{2 R}\left(x_{k}\right)^{T} R\left(x_{k}\right)+\left(x-x_{k}\right)^{T} J\left(x_{k}\right)^{T} R\left(x_{k}\right) \\
& +\frac{3}{J}\left(x-x_{k}\right)^{T}\left[J\left(x_{k}\right)^{T} J\left(x_{k}\right)+s_{k}\right]\left(x-x_{k}\right) .
\end{aligned}
$$

We will suggest an approximation rule for $s_{k}$ which is siagle, general and geometric. The approach is to decide on set of desirable characteristics for the approximant and then to select $S_{k+1}$ to be the nearest such feasible point to $8_{k}$. The rationale is that every point in the feasible set incorporates equally rell the new information gained at $x_{k+1}$ and that taklng the nearest 
polnt (lo a sense to be explained later) corresponds to destroylng as littlo of the information stored is $\mathrm{S}_{\mathrm{k}}$ as possible.

curreatly ve beglo with $S_{0}-0$. since tilis is botb cheap and reaconablo in the sease tiat $q_{0}^{S}=q_{0}^{G}$. Sugpose $s_{k}$ is avallable. Frot let us decide on the propert1 $\xi_{k+1}$ should bare. Rezezber that 1t 1s to approximate $\operatorname{lr}_{1}\left(x_{k+1}\right) \nabla^{2} r_{1}\left(x_{k+1}\right)$ and so it should obvicusly be syzectric. It is easy to find examples where the term to be approxirated is Indesinite, so ve reject ans restriction on the elgenralues of $s_{k+1}$. Firally, we wapt to incorporate the new information about the frodles. $J_{k+1}$ and $B_{k+1}$, Into $S_{k+1}$. The standard vay to do this 1 so to ask the second order approxixant to transform the current $x$-change into the observed flrst order change, 1.e.

$$
s_{x+1} \Delta x_{k}=\Sigma s_{1}\left(x_{x+1}\right) \nabla^{2} x_{1}\left(x_{x+1}\right) \Delta x_{k}
$$

$$
\begin{aligned}
& =\left[x_{1}\left(x_{k+1}\right)\left(\nabla x_{1}\left(x_{k+1}\right)-\nabla x_{1}\left(x_{k}\right)\right)\right. \\
& -J_{k+1}^{T} R_{k+1}-J_{k}^{T} R_{k+1} \equiv y_{k} .
\end{aligned}
$$

It 10 perhaps rorth ooting in passing that we tested several cholcen for $Y_{k}$ lacluding the Broyden-Denn1s [Denn1s, 1973] cholce $J_{k+1}^{T} R_{k+1}-J_{k}^{T} R_{k}-J_{k+1}^{T} J_{k+1} d k_{k}$ and the Betts (1976) cholce $J_{k+1}^{T} R_{k+1}-J_{k}^{T} R_{k}-J_{k}^{T} J_{k} \Delta x_{k}$. Happ12y, (3.2), which eakes sors use of the structure of the problcm, was the slight but clear winner. In si=ary, ve choose $s_{0}=0, s_{k+1} \subset \mathcal{S}-$ (s: $s=s^{T}$ and $s \Delta x_{k}-y_{k}$ ).

our cholce of $s_{k+1}$ srow \& 10 made in analogy with the DPP method sor uncosstralised minloliation [Dennls pore, 1977]. Before giving the formula and 1te progertlee, we rovlov une usorul nutalion.

If $A$ is any real matrix, then the frobenlus norm of $A$ ls $\|A\|_{Y} \equiv\left(u_{1 j}^{2}\right)^{\frac{1}{2}}$. If $B$ is any oymetric positive derinite matrix, then 
B has a aymetrie, positive definite square root, $B^{\frac{2}{2}}$. Define $\|A\|_{F, B}=\left\|B^{-2 /} A B^{-\frac{1}{2}}\right\|_{P}$. This velghted Frobenius nor 18 a astural analog of the Frobenlus norm for a matrlx wen the starcard isner product

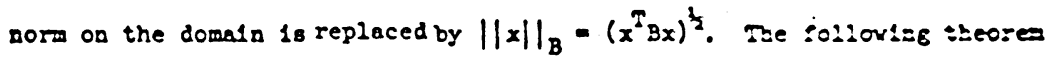
Blves the update formulas as vell as thelr defining properties. It is just a restatement of Theorem 7.3 of (Deanls and Yore, 2977).

MYSOREM 3.1: Let $v^{T_{\Delta x}}>0$. Then for ay positive de:isite sy=etric matrix \& sor valcb $8 \Delta x_{x}=v$.

$$
\text { min }\left\|s-s_{x}\right\|_{8,8} \text { for } 5 \text { \& \& }
$$

1. colved by

$$
\begin{gathered}
8_{k+1}=8_{k}+\frac{\left(y_{k}-s_{k} \Delta z_{k}\right) \nabla^{T}+r\left(y_{k}-s_{k} \Delta z_{k}\right)^{2}}{\Delta x_{k}^{T} r}- \\
-\frac{\Delta x_{k}^{2}\left(y_{k}-s_{k} \Delta x_{k}\right) r r^{T}}{\left(\Delta x_{k}^{2} \nabla\right)^{2}}
\end{gathered}
$$

In xL280L ve compute $B_{k+1}$ corresponeing to $v-L_{k} \cdot j_{k+1}^{T} P_{k+1}-j_{k}^{T} P_{k}$ Thle corrosponds to velgbting the change by any positire cersa:te syzetric matrlx that cends $\Delta x_{k}$ to $\Delta E_{k}$. Thus ve nope the matrle beine leet is not too different frow that laduced by the natural acallog of tie problem. 


\section{Sizine the Fessian Augrentation.}

It 1 s well known by now that the update methods do not generate approximations that become arbitrarily accurate as the 1teration proceeds. On the other hand, we know that for zero residual problems, $s_{k}$ should 1deally converge to zero and that if 1 t does not at least become small in those cases, then the augmented model (3.1) cannot hope to compete w1th (2.6), the rauzs-lawion metal.

The crux of the problem can be seen by observing that even if $R_{k+1}$ tisjounel to be zero and even $1 f y_{k}$ defined by (3.2) were used to make the update to $S_{k}$, then $S_{k+1} \Delta x_{k}=y_{k}=0$, but $S_{k+1}$ would be the same as $S_{k}$ on the orthogonal complement of $\left\{\Delta x_{k}, v\right\}$.

We use a straightforward modification of the Oren-Luenburger self scaling technique [Oren, 1973]. The idea is to update $\tau_{k} S_{k}$, rather than $S_{k}$, to get $S_{k+1}$. The scalar $T_{k}$ is chosen to try to shift the spectrum of $S_{k}$ in hopes that the spectrum of $\tau_{k} S_{k}$ will overlap that of the second order term ve are epproximating. We could take the scalar to be

$$
\frac{\Delta x_{k}^{T} y_{k}}{\Delta x_{k}^{T} S_{k} \Delta x_{k}} \div\left[\frac{\Delta x_{k}^{T}\left[\sum r_{1}\left(x_{k+1}\right) \nabla^{2} r_{1}\left(x_{k+1}\right)\right] \Delta x_{k}}{\Delta x_{k}^{T} \Delta x_{k}}\right]\left[\frac{\Delta x_{k}^{T} S_{k} \Delta x_{k}}{\Delta x_{k}^{T} \Delta x_{k}}\right]-1
$$

We prefer to call this sizing, and since ve are primarily concerned with $S_{k}$ being too large, ve actually take

$$
\tau_{k}=\min \left\{\left|\frac{\Delta x_{k}^{T} y_{k}}{\Delta x_{k}^{T} S_{k} \Delta x_{k}}\right|, 1\right\} \text {. }
$$


Whatever this strategy is called, notice that when $R_{k+1}=0$, our $y_{k}=0$, and so $\tau_{k}=0$ and $S_{k+1}=0$. The use of sizing sactor (4.1) made a Bignificant difference in the performance of the algorithm. See Table IV.

5. Adaptive Quadratic Modeling.

In section 3 we noted that $s_{0}=0$, which means that the augmented rodel (3.1) 1s Initially equal to the Gauss-Nowton model (2.6). Tests have shom that often $q_{k}^{G}\left(x_{k+1}\right)$ predicts $f\left(x_{k+1}\right)$ better than $q_{k}^{S}\left(x_{k+1}\right)$ for small $k$, so it seems useful to have some way to decide which model to use to deteraine the step.

Betts [1976] also starts with $S_{0}=0$ and takes Gauss-Nevton steps for at least $p$ iterations and unt1l $\Delta x_{k}$ is small enough to make it 1ikely that $x_{k+1}$ is near $x^{*}$. It seems therefore as though his ain is to make a last few refining iterations based on the augmented Bessian. The heuristic we use in NL2SOL ususily uses the augmented Hessian much sooner. NL2SOL uses a model/trust region strategy to pick $\Delta x_{\mathbf{k}}$. The step is of the form

$$
\Delta x_{k}=-\left(\lambda_{k} D_{k}^{2}+H_{k}\right)^{-1} \nabla f\left(x_{k}\right)
$$

where $H_{k}$ is the current hessian approximation, $D_{k}$ is a diagonal scaling matrix and $\lambda_{k} \geq 0$ is chosen by the safeguarded Reinsch iteration as in [More, 1978], with the case of near singularity in $\lambda_{k} R_{k}^{2}+r_{k}$ handied as in [Gay, 1979]. The important thing is the 1dea of having at $x_{k}$ a local quadratic model $q_{k}$ of $f$ and an estimate of a region in which $q_{k}$ is trusted to represent 5 . The next point $x_{k+1}$ is chosen to approximately ninimize $q_{k}$ 
In this region or to alnisize $q_{x}$ in an approximation to this reglon. In eltber case, the information galned ebout $f$ at $x_{x+1}$ is then used to . update the Dodel and also to uplate the alze or shape of the trust reglon.

We begla vith the assuiption that $q_{0}^{C}$ holds globally. Since the trust regios rerision is alvays based on the length of the step just taiken, thla causes the radius to be set automatically by the infital Gauss-Nerton step. This schere often vorks vell, but 1 t can have problems. If the GassoNevioz step is too long, the trust region may have to be shrunk repeatediy witb attendant eraluatioss of the residual sunction $R$ to obtain an acceptable $x_{I}$. kich nore serious is the possiblility of overflow. The infitial assurption of glotal linearity can be overruled by assigning a small value to $V($ LMAXO), the zaxlaus length allowed for the very flrst step atterpted.

Fisure 1 vill perhaps be helprul at this point. The ellipoes represent the contours of $q_{k}$ and the clrcle is the trust region -- our pleture assumes the diagonal scaling matrix $q_{k}$ to be the ldentity. The polnt $N_{k}$ is the "Merton step" or global minioum of the conrex quadratic model $q_{k}$, and the curve $\theta(x)$ represents the locus of alnimizers of $q_{k}\left(x_{k}+8\right)$ constralned by $\|s\|_{2} \leq r, 0<x<\infty$. Complete detalls, based largeiy on [More, 1978], can be foind in [Gay, 1979], but we choose $\Delta x_{k}=s(r)$ so that $\left\|D_{k} \Delta x_{k}\right\| \|_{2}$ 11es between 0.9 and 2.1 of tho current trust radius. (The actual cholco of $D_{k} 10$ discuased In Sect100 7.)

slace we vere using thle adaptive approach, 1t 10 not ourprlalng that ve also thougbt of using the new information at $x_{x+1}$ to select between $q_{x+1}^{5}$ and $q_{x+1}^{G}$ for use in detefinining $x_{x+2}$. Our decision rule 10 rather 


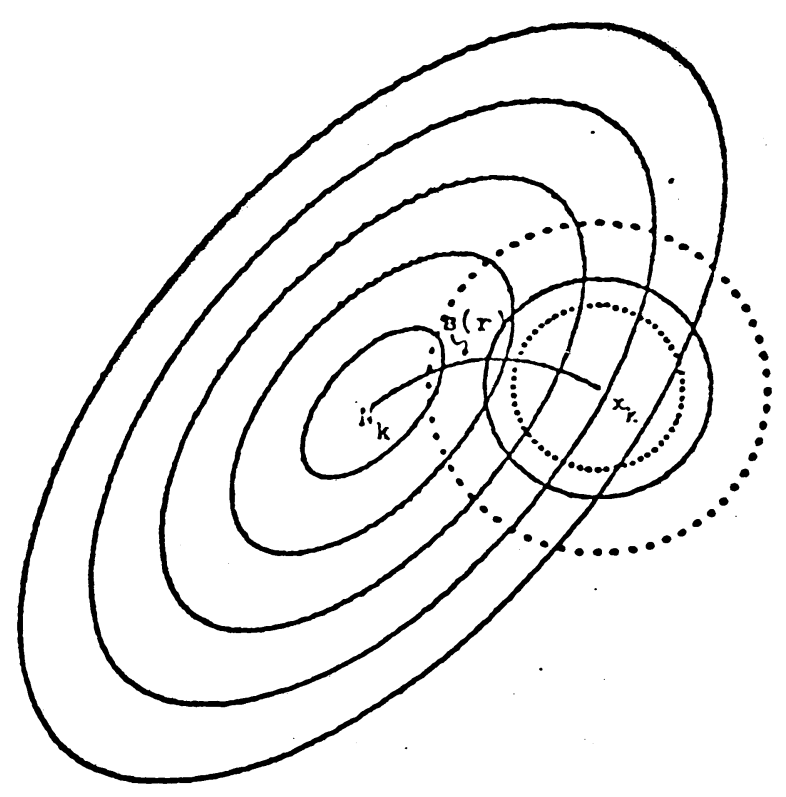

Plouro I 
straightforward. Since $S_{0}=0$, we begin using the Gauss-Newton model. Arter making a prospective step based on the currently preferred model $q_{k}^{l}$ to obtain, say, $x_{k+1}^{1}$, we compute $R_{k+1}^{1}$ and $f_{k+1}^{1}$. If $f_{k+1}^{1}>f_{k}$ then $x_{k+1}^{1}$ is discarded, but first the other model $q_{k}^{2}$ is evaluated at $x_{k+1}^{1}$ to see how well it agrees with $f_{k+1}^{1}$. If there 18 not sufficient agreement between $r_{k+1}^{1}$ and $q_{k}^{2}$ (i.e., if

$$
\left.\left|q_{k}^{1}\left(x_{k+1}^{1}\right)-p_{k+1}^{1}\right| \leq 2^{\frac{3}{2}}\left|q_{k}^{2}\left(x_{k+1}^{1}\right)-r_{k+1}^{1}\right|\right) \text {, }
$$

tren we kanp the orlpinal model preference, shrink the trust repion, and try again. We shrink the trust region radius by the factor suggested by Fletcher [1971] and described by Nore [1978, p. 109]. If the agreement between $p_{k+1}^{1}$ and $q_{k}^{2}\left(x_{k+1}^{1}\right)$ is surficiently good, then we change our model preference to $q_{k}^{2}$ and compute $x_{k+1}^{2}$ using the same trust region. If $x_{k+1}^{2}$ is unacceptable, then the trust region 18 shrunk and we repeat the abore process on the smaller trust region with whichever model gave the least runction value, but now we no longer consider changing models while continuing to seek an acceptable $x_{k+1}$.

If, say $x_{k+1}^{1}$ y'lelds an acceptable function decrease but

$$
\begin{aligned}
f\left(x_{k+1}^{1}\right)-f\left(x_{k}\right) \leq & \max \left(10 \cdot\left[z_{k}^{1}\left(x_{k+1}^{1}\right)-f\left(x_{k}\right)\right],\right. \\
& \left.0.75 \cdot \nabla f\left(x_{k}\right)^{T}\left(x_{k+1}^{1}-x_{k}\right)\right\}
\end{aligned}
$$

and $\Delta x_{k}=x_{k+1}^{1}-x_{k}$ was computed by (5.1) with $\lambda_{k}>0$, then we deem it vortbuhlle to try recomputing $x_{k+1}^{1}$ with a larger trust region radius before accepting the step. Hence ve double the radius and obtain, say, $x_{k+1}^{1^{\prime}}$. If $f\left(x_{k+1}^{\lambda^{\prime}}\right)<f\left(x_{k+1}^{1}\right)$, then $x_{k+1}^{1^{\prime}}$ replaces $x_{k+1}^{1}$ and we again check whether to double the radius. Otherwlse ve discard $x_{k+1}^{1^{\prime}}$ and accept $x_{x+1}^{1}$ \&s $x_{x+1}$. 
When an acceptable $x_{k+1}$ is found, $q_{k}^{1}\left(x_{k+1}\right)$ and $q_{k}^{2}\left(x_{k+1}\right)$ are compared to $Y_{k+1}$. We have found that it lo best to retain the currentiy preferred model if (5.2) holds with $x_{k+1}^{1}=x_{k+1}$, 1.e., unless the other model does a significantly better job of predicting the nev function ralue.

Once $x_{k+1}$ has been found, we declde what trust region radius to use first when seeking $x_{k+2}$. The radius chosen has the form $u\left\|D_{k+1} \Delta x_{k}\right\| \|_{2}$, where $\Delta x_{k}=x_{k+1}-x_{k}$. If $f\left(x_{k+1}\right)-f\left(x_{k}\right) \geq 0.1 \cdot\left[a_{k}^{1}\left(x_{k+1}\right)-f\left(x_{k}\right)\right]$, tren $n$ is Fletcher's [1971] decrease factor; if elther (5.3) bolds vith $x_{x+1}^{1}=x_{x+1}$. or $\left\|\nabla^{2} a_{k}^{1} \Delta x_{k}-\left[\nabla r\left(x_{k+1}\right)-\nabla r\left(x_{k}\right)\right]\right\|_{2} \leq 0.5\left\|\nabla f\left(x_{k+1}\right)\right\|$, or $\Delta x_{k}^{T} \nabla f\left(x_{k+1}\right)<0.75 \cdot \Delta x_{k}^{T} \nabla f\left(x_{k}\right)$, then $\mu=2$; otherwlse $\mu=1$. This rule for updating the radius is a modification of one described by Povell [1970].

\section{Convergence Criteris and Covariance.}

An 1mportant, sometimes difficult issue in practical computing is the matter of deciding when to stop an iterative procedure. We have chosen to Include four convergence criteria in NL2SOL: tests for "cosine convergecce", "variability convergence", "residual convergence", and " $x$-convergence".

At any critical point of the sum of squares runction (2.1), such as the desired minimizer $x *$, the residual vector $R$ is orthogonal to all coluens of the Jacoblan matrix J. Moreover, the angles between $R$ and the coluans of $J$ are independent of the scale of $R$ and columns of $J$, so it is reasonable to use test based on these angles [Dennis, 1977]. Hence, ve define (6.1) $\operatorname{cosmx}(x)=\left\{\begin{array}{l}0 \text { if } R(x)=0 \\ \max \left(\left|J_{\cdot, 1}(x)^{T} R(x)\right| /\left(\left\|J_{\cdot, 1}(x)\left|I_{2}\|R(x)\|\right|_{2}\right)\right.\right. \\ \left.:\left\|J_{\cdot, 1}(x)\right\|>\epsilon_{J 1}, 1 \leq 1 \leq p\right\} \\ \text { otherwise, }\end{array}\right.$ 
were $J ., L(x)$ 1s the 1 th colum of $J(x)$, and we detect cosine conrergence at ary lterate $x_{k}$ for valch $\operatorname{coshax}\left(x_{k}\right)$ 1s less than or equal to the cosioe coetergence tolerence $v(\cos C R)$. By default, $F_{J 1}=10^{-9}$, so the $\cos M a x 10$ scaie latrafiast over a vide range or problens.

For statistical deta analysis a different type of convergence criterion 1s orten appropriate. Since there 1s inherent variability in the data, it is ceseraily oct userul to contlnue lterating when a candidate step $\operatorname{so}\left(\theta_{0}^{1} \ldots, s^{P}\right)=\Delta x_{K}$ 18 geverated for walcb

$$
\cos _{1}\left(\left|s^{1}\right| / 8 \cdot e \cdot\left(x_{k}^{1}\right)\right)
$$

1s sufficleatly mall. Bere s.e. $\left(x_{k}^{1}\right)$ denotes somo ostlmate of the atandard error (square root of the rarlance) of the th cosponent of the current parameter estiate $x_{x}$ asc so 1a a runction of the statlotical varlablilty in the data.

As arterative to (6.2) suggested by Pratt [1977) 1s to consider general Linear cosblantions $l^{T}$ of the components of $, 1,0$.

$$
\operatorname{sax}\left(\left|l^{T}:\right| /\left(l^{T} V_{k} l\right)^{\frac{3}{2}}: l \neq 0\right)=\left(s^{T} v_{k}^{-1} s\right)^{\frac{1}{2}}
$$

vere $v_{k}$ is a current est1mate of the covarlance matr1x. For a.e. $\left(x_{k}^{1}\right)$

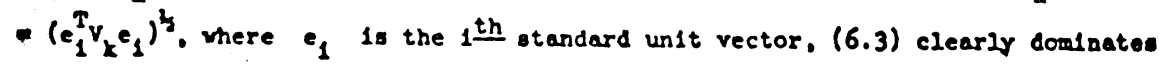
(6.2). so ve have chosen to Include a test based on (6.3).

our cbolce for $V_{k}$ was $\hat{\sigma}_{k}^{2} k_{k}^{-1}$, where $\hat{o}_{k}^{2}$ 1s the current residual sum of squares dirided by $\max \{1, n-p\}$, 1.e.

$$
\dot{o}_{k}^{2}=2 \rho\left(x_{k}\right) / \max (1, n-p) \text {. }
$$

and ${ }_{2}$ 10 the curreat Hessian approximation, 1.0. $J^{T} J\left(x_{x}\right)$ for the Caussderton sodel and $J^{n} J\left(x_{k}\right)+s_{k}$ for the auemented model. Whenever a candidato 


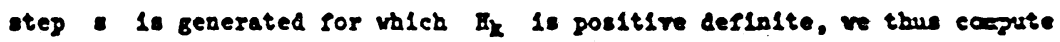

$$
\operatorname{vaPIAB}(s)=s^{T_{x}} \cdot / \tilde{\sigma}_{x} \text {. }
$$

and we detect rariabillity costergence is Vhisha(s) does bot exceed the varindility contergeace tolerance $V$ (VCORCR).

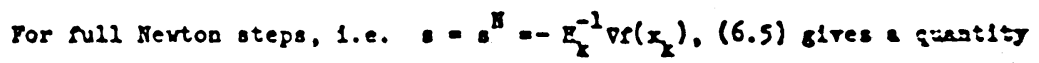
elosely related to the relative reduct100 $P P E D_{k}, 10 \mathrm{~g}\left(z_{k}\right)$ that $18 \mathrm{st:12}$ poselble according to the current zodel. Epecielcally, $(6.5)$ ass $(6.6)$ is:

$$
\begin{aligned}
& P R E D_{k}=\left[-\nabla P\left(x_{k}\right)^{T} B-\frac{1}{2} e^{X T} R_{k}{ }^{D}\right] / S\left(x_{k}\right) \\
& -\frac{1}{2} x^{T} H_{x} \cdot x / s\left(x_{x}\right) \\
& \text { - } \operatorname{VARTAB}\left(0^{R}\right) / \text { rax }(1, n-p)
\end{aligned}
$$

Thus at least for oull Revton steps (the steps usually tarea ceer $x \%$ ), the varlablilty convergence test checks whether the predlcted relatire resuet100 st111 posible in the residual sur of squares is sall.

Zero-redlusl problems, those sor whlch $R\left(x^{\circ}\right)$ - 0, regulzo spes:e: consideration. Indeed, it can be shown that if $J\left(x^{\circ}\right)$ is nossiaguier, thes

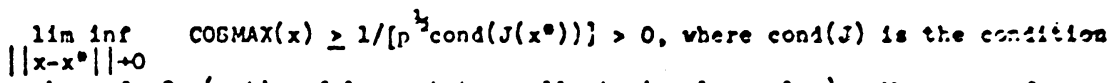
number of $J$ (ratio of largest to sablest singular ralue). Borecter, so

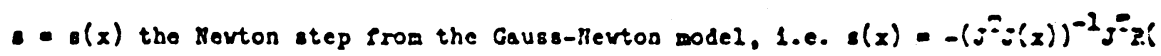

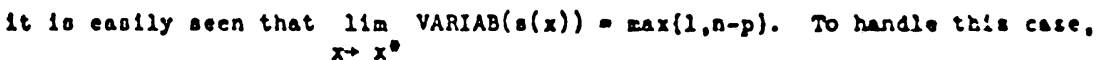
NL2SOL detects residual convergence is $\left\|R\left(x_{x}\right)\right\| \leq V(R C O S C R)$. We regret itat thle convergence teot aust be sensitive to the scalling of $R$. 
It is easy to specify convergence tolerances too strict for the precision of the arithmetic being used. We have therefore included a fourth convergence test, the $x$-contergence test, which often works when overly tight tolerances hare been given for the other tests. This test is satisfied whenerer a step s is generated that yields a much smaller function decrease than expected (1.e. $\left.f\left(x_{k}+s\right) \geq f\left(x_{k}\right)+s^{T} \nabla f\left(x_{k}\right) / 10\right)$ and the relative change that $s$ causes In $x_{k}$ is sall, 1.e. $\operatorname{RELDX}\left(x_{k}, x_{k}+8\right) \leq v(x \operatorname{CONCR})$, where

$$
\operatorname{RELDX}(y, z)=\max _{1}\left|z_{1}-y_{1}\right| /\left[\left|z_{1}\right|+\left|y_{1}\right|\right]
$$

May statistical inference procedures require an estimate of the covariance matr1x at the solution $x^{*}$. ML2SOL provides three possibilities:

$$
\hat{\sigma}^{2} \mathrm{~B}^{-1} \mathrm{~J}^{\mathrm{T}} \mathrm{J} \mathrm{B}^{-1}
$$

$$
\hat{\sigma}^{2} \mathrm{~B}^{-1}
$$

$$
\hat{\sigma}^{2}\left(J^{T} J\right)^{-1}
$$

were $\dot{\sigma}^{2}$ is given by (6.4) with $x_{k}=x^{*}$. When $(6.6)$ or (6.7) is specified, a symetric pinite difference Hessian approximation $\mathrm{B}$ is obtained at the solution, $x^{*}$. If 1 is positive definite lor $J$ is non-singular at $x^{*}$ for $(6.8)$ ], the specifled covariance matrix is computed.

A detalled discussion of all three covariance forms is contained in [Bard,1974]. Tye secozt form (5.7) is based on asymptotic maximum likelihood theory and is perhaps the most comon form of estimated covariance matrix. We feel that (6.6), the, default, is more useful for smaller sample sizes and in other cases where the conditions necessary [Ro, 1965] for the asymptotic theory may be violated. The third form assumes that the residuals at the solution are small and is therefore often highly suspect. 


\section{Test Results}

We have run NS2SCL on number of the test problems reported in the 1iterature. In particular, we have run it on the test problems isted in [G111 Murray, 1976] and on one described in [Meyer, 1970]. The origlnal sources for these problers, together with the abbreviated problem nanes used in Tables II-IY and some notes, are given in Table I.

\section{Table I}

Original Sources of Test Problems

\begin{tabular}{|c|c|c|}
\hline Problem & Note & Source \\
\hline ROSHBROK & & [Rosenbrock, 1960] \\
\hline HELIX & 1 & [Fletcher \& Porell, 1963] \\
\hline SINGULAR & & [Powell, 1962] \\
\hline WOODS & & [Colvilie, 1968] \\
\hline ZANGWILL & 2 & [Zangwill, 1067 ] \\
\hline ENGVALL & & [Engva11, 1966] \\
\hline BRAN IN & & [Branin, 1971] \\
\hline BEALE & & [Beale, 1958] \\
\hline CRAGG & 3 & [Gill \& Murray, 1976] \\
\hline BOX & & {$[$ Box, 1966] } \\
\hline DAVIDON 1 & 4 & [Davidon, 1976] \\
\hline FRDSTEIN & 5 & [Freudenstein Roth, 1963 \\
\hline $\begin{array}{l}\text { WATSON } 6,9,12,20 \\
\text { CHEBQD8 }\end{array}$ & & $\begin{array}{l}\text { [Kowal1k \& Osborne, 1968] } \\
\text { [Fletcher, 1965] }\end{array}$ \\
\hline BROWN & 6 & [Brown \& Dennis, 1971] \\
\hline BARD & & [Bard, 1970] \\
\hline JENNRICH & & [Jennrich \& Sampson, 1968] \\
\hline KOWALIK & & [Kowalik osborne, 1968] \\
\hline OSBORNE1, 2 & & [Osborne, 1972] \\
\hline MEYER & & [Meyer, 1970] \\
\hline
\end{tabular}

\section{Notes on Table I}

Note 1: The residual vector $R(x)$ for this problem is a discontinuous function of $x$. On those runs where NL2SOL halts with $x$-convergence, the iterates have converged to a point of discontinulty.

Note 2: This is a linear least-squares problem which NL2SOL solres in one step when the limit $V$ (LMAXO) on the length of the first step is increased slightly from 1ts default value.

Note 3: The original kiele problem described in [Crags \& Levy, 1969], vhlch Gill and Murray [1976] cite as the source for this problen, does not have tie last residual component $r_{5}(x)=x_{4}-1$. This nev component forces $x_{4}$ to move more rapidy towards 1 , but otherwise causes no noteworthy change in the performance given by nL280L. 
Iote 4: Fais is anotber lloear least-squares probiea, ose that 18 00 12 ecsililones that $5: 250 L$ needs two steps to solve 1 thes using double presision on an IZY 370 computer vith $V($ L's:Xo) set large. With a doublo precis:cn of a few blts nore accuracy, such as that of the MLTic3 (1.0.

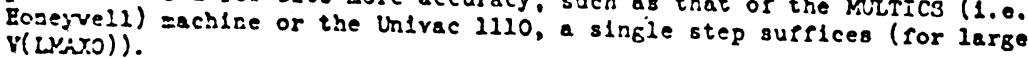

Note 5: In all our test runs, NL2SOL found a local solution to this probies. The residial rector vanishes at the global solution,

liote 6: C1ll and purray [1976] call tbla problem "Davidon 2".

The behavior of KL2SOL is determined in part by an integer array IV ada - Nloat1sz-polat array $v$, whlch contalo lteration and function evaluation limits, costergesce tolerances, and other sultches and constants. In the runs sumarized Ia Tables II-IV, aost of the IV and $V$ infut components had the default values glred ties by subroutine DFAUTT. Exception included the following: variablilty cosrergeace testirg was turaed off by setting $V(V$ CONCR) - 0 ; and on problem VEYSR, the 1teration and function-evaluation 11 mits vere increased.

rable II sumearlies the performance of NL2SOL on the test problem sot viea all IV and $V$ input cosponents have thelr default values, with the exceptions gust noted. Folloving a suggestion of J.J. More [1979], we obtalned new starting guesses for mazy of the test problems by multiplying the standard stertling guess by ten and one hundred. The colum labslled is glveo the base 10 logaritha of the ractor by whlch the standard starting guess vas cultiplied. The problem dimensions appear in the colurna headed $W$ and $P$. whlle tie aueber of sunction (1.e. $R(x)$ ) and gradient (1.e. $J(x)$ ) evaluatlons persorzed respectively appear under $\mathrm{KF}$ and NG. The column labelled $\boldsymbol{Y}$ gives the slanl ruction ralue (half the sum of squares of $R(x)$ ), whlle the one lebeled cosmax gives coskax $(x)$, computed from $(6.1)\left(\right.$ with $\left.\sigma_{J 1}-10^{-9}\right)$,

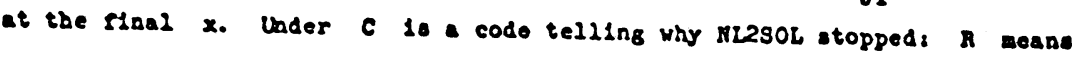


residual costergence, 1.e.. $\|R(x)\|_{2} \leq 10^{-9}$; $C$ meas cosise costergesce. 1.e. $\cos v a x(x) \leq 10^{-7} ; x$ means $x$ convergence (see 36$) \mathrm{rts}$

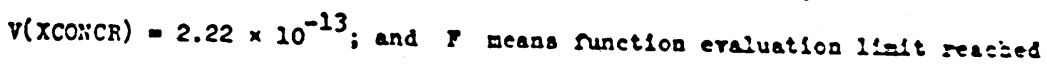
vitiout convergence. The results reported in Tables II-IV vere ob:al=es co

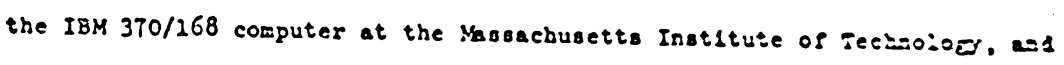
the convergence tolerances just mentloned are the defauls for tz:s gacklse, whlch has a undt roundoss of $16^{-13}: 2.22 \times 10^{-16}$ 10 doutie frecls: $=2$. the precision used.

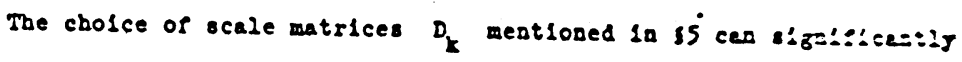

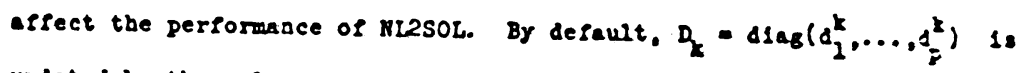
updated by the rulo

$$
d_{1}^{k}=\max \left(\left[\|J \cdot, 1\|_{2}^{2}+\max \left(0,9_{11}\right)\right\}^{\frac{1}{2}}, 0.6 e_{1}^{k-1}, 20^{-3} j\right.
$$

at the start of each 1teration, begianing with $d_{1}^{-1}=0$, vhere $J ., 1$ desoses the th colum of the current Jacoblan matrlx $\mathrm{J}\left(\mathrm{z}_{\mathrm{k}}\right)$. (The sactor 0.6 Is

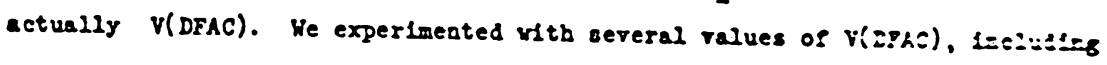
2ero, $0.5,0.75$, and one, and we selt that 0.6 gare the best oreadi je:porsase of the ralues tried.) The advantage of this cbolce of $q_{x} 18$ tist it is largely scale-invariant.

A cholce of $D_{k}$ whicb lo not at all scale-invarlent, but wick gives better

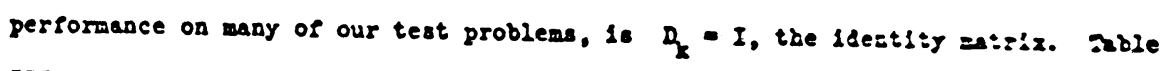
III howe how these two cholces of $D_{k}$ compare: results sroe tabje $i d$ are rejest In the columns beaded DEFAULT, vhlle results correspondlog to $q_{K}$ - I azpear under $D=I$. 
Table III also gives results from two other test runs. Those unier $V(L$ MaY $J)=1 C$ wh show what happens when the bound $V($ LMAXO) on the 2-norm of the very flrst step attempted 18 increased from 1ts default value of 100 to $10^{10}$, while those under $V(C \operatorname{CoN} C R)=10$ n -8 show what happens when the cosine convergence tolerance 1s decreased from $10^{-7}$ to $10^{-8}$. In both of these test runs the default $D_{k}$ was used. 


$$
\begin{gathered}
\text {-19- } \\
\text { Trble II } \\
\text { Derault Nivici Tast Jimst:ry }
\end{gathered}
$$

\begin{tabular}{|c|c|c|c|c|c|c|c|c|}
\hline$M$ & LS & H & $P$ & $N F$ & NG & C & $\boldsymbol{P}$ & cosynx \\
\hline $\begin{array}{l}\text { ROS:ABKOK } \\
\text { ROSABROK } \\
\text { ROS:IBROK }\end{array}$ & $\begin{array}{l}0 \\
1 \\
2\end{array}$ & $\begin{array}{l}2 \\
2 \\
2\end{array}$ & $\begin{array}{l}2 \\
2 \\
2\end{array}$ & $\begin{array}{r}15 \\
45 \\
156\end{array}$ & $\begin{array}{r}13 \\
36 \\
135\end{array}$ & $\begin{array}{l}\mathrm{R} \\
\mathrm{R} \\
\mathrm{R}\end{array}$ & $\begin{array}{l}0.973 F-32 \\
0.973 E-32 \\
0.973 E-32\end{array}$ & $\begin{array}{l}0.099 F+00 \\
0.999 E+00 \\
0.999 E+00\end{array}$ \\
\hline ELIX & $\begin{array}{l}0 \\
1\end{array}$ & 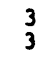 & 3 & 15 & $\begin{array}{l}13 \\
10\end{array}$ & $\begin{array}{l}\mathbf{R} \\
\mathbf{R}\end{array}$ & $\begin{array}{l}0.323 E-18 \\
0.221 E-23\end{array}$ & $\begin{array}{l}0.10 C E+01 \\
0.777 E+00\end{array}$ \\
\hline $\begin{array}{l}\text { HELIX } \\
\text { SINGULAR }\end{array}$ & $\begin{array}{l}2 \\
0\end{array}$ & $\begin{array}{l}3 \\
4\end{array}$ & $\begin{array}{l}3 \\
4\end{array}$ & $\begin{array}{r}125 \\
18\end{array}$ & $\begin{array}{l}37 \\
18\end{array}$ & $\begin{array}{l}X \\
R\end{array}$ & $\begin{array}{l}0.664 E+04 \\
0.273 E-18\end{array}$ & $\begin{array}{l}0.744 E+00 \\
0.962 E-04\end{array}$ \\
\hline $\begin{array}{l}\text { SINGULAR } \\
\text { SINGUIAR }\end{array}$ & $\begin{array}{l}1 \\
2\end{array}$ & $\begin{array}{l}4 \\
4\end{array}$ & 4 & $\begin{array}{l}22 \\
30\end{array}$ & $\begin{array}{l}22 \\
26\end{array}$ & $\begin{array}{l}\mathbf{R} \\
\mathbf{R}\end{array}$ & $\begin{array}{l}0.806 E-19 \\
0.849 E-19\end{array}$ & $\begin{array}{l}-04 \\
-04\end{array}$ \\
\hline $\begin{array}{l}\text { WOODS } \\
\text { WUODS }\end{array}$ & $\begin{array}{l}0 \\
1\end{array}$ & $?$ & 4 & $\begin{array}{l}56 \\
64\end{array}$ & $\begin{array}{l}43 \\
44\end{array}$ & $\begin{array}{l}\mathbf{R} \\
\mathbf{R}\end{array}$ & & $\begin{array}{l}\varepsilon+\infty O \\
E+\infty O\end{array}$ \\
\hline WOODS & 2 & 7 & 4 & 75 & 51 & $\mathbf{R}$ & $0.523 E-23$ & $1 E+00$ \\
\hline ZANGWILL & 0 & 3 & 3 & 3 & 3 & $\mathbf{R}$ & 0.147 & $+\infty 0$ \\
\hline $\begin{array}{l}\text { ENGVALL } \\
\text { ENGVALL }\end{array}$ & $\begin{array}{l}0 \\
1\end{array}$ & $\begin{array}{l}5 \\
5\end{array}$ & $\begin{array}{l}3 \\
3\end{array}$ & $\begin{array}{l}16 \\
20\end{array}$ & $\begin{array}{l}13 \\
19\end{array}$ & $\begin{array}{l}\mathbf{R} \\
\mathbf{R}\end{array}$ & & $\begin{array}{l}0.999 E+00 \\
0.999 E+00\end{array}$ \\
\hline ENGVALL & 2 & 5 & 3 & 27 & 26 & $\mathbf{R}$ & $0.882 \mathrm{E}-19$ & $0.99 \subseteq E+00$ \\
\hline BRAN IN & $\begin{array}{l}0 \\
1\end{array}$ & $\begin{array}{l}2 \\
2\end{array}$ & $\begin{array}{l}2 \\
2\end{array}$ & $\begin{array}{r}2 \\
16\end{array}$ & $\begin{array}{r}2 \\
15\end{array}$ & $\begin{array}{l}\mathbf{R} \\
\mathbf{R}\end{array}$ & & $\begin{array}{l}5 E+00 \\
5 E+00\end{array}$ \\
\hline BRANIN & 2 & 2 & 2 & 15 & 12 & $\mathbf{R}$ & $0.864 E-32$ & $55+00$ \\
\hline $\begin{array}{l}\text { BEA } \\
\text { BEA }\end{array}$ & $\begin{array}{l}0 \\
1\end{array}$ & $\begin{array}{l}3 \\
3\end{array}$ & $\begin{array}{l}2 \\
2\end{array}$ & $\begin{array}{r}10 \\
6\end{array}$ & $\begin{array}{l}9 \\
6\end{array}$ & $\begin{array}{l}\mathbf{R} \\
\mathbf{R}\end{array}$ & & $\begin{array}{l}+00 \\
+00\end{array}$ \\
\hline CRAGG & 0 & 5 & 4 & 22 & 21 & $\mathbf{R}$ & $0.289 E-18$ & $7 E+00$ \\
\hline $\begin{array}{l}\text { CRAGG } \\
\text { BOX }\end{array}$ & $\begin{array}{l}1 \\
0\end{array}$ & $\begin{array}{r}5 \\
10\end{array}$ & $\begin{array}{l}4 \\
3\end{array}$ & $\begin{array}{l}75 \\
20\end{array}$ & $\begin{array}{l}43 \\
14\end{array}$ & $\begin{array}{l}\mathbf{C} \\
\mathbf{R}\end{array}$ & $\begin{array}{l}0.592 E+02 \\
0.167 E-22\end{array}$ & $\begin{array}{l}-07 \\
+00\end{array}$ \\
\hline $\begin{array}{l}\text { BOX } \\
\text { BOX }\end{array}$ & $\begin{array}{l}1 \\
2\end{array}$ & $\begin{array}{l}10 \\
10\end{array}$ & $\begin{array}{l}3 \\
3\end{array}$ & $\begin{array}{l}19 \\
23\end{array}$ & $\begin{array}{l}11 \\
14\end{array}$ & $\begin{array}{l}\text { C } \\
\text { C }\end{array}$ & & \\
\hline DAVIDONI & 0 & 15 & 15 & 9 & 8 & C & $0.710 \mathrm{E}-04$ & \\
\hline FRDSTEIN & 0 & 2 & 2 & 8 & 7 & C & & 08 \\
\hline $\begin{array}{l}\text { FRDSTEIN } \\
\text { FRDSTEIN }\end{array}$ & $\begin{array}{l}1 \\
2\end{array}$ & $\begin{array}{l}2 \\
2\end{array}$ & $\begin{array}{l}2 \\
2\end{array}$ & $\begin{array}{l}19 \\
35\end{array}$ & $\begin{array}{l}12 \\
19\end{array}$ & $\begin{array}{l}\mathbf{C} \\
\mathbf{C}\end{array}$ & & \\
\hline & $\begin{array}{l}0 \\
0\end{array}$ & & $\begin{array}{l}6 \\
9\end{array}$ & $\begin{array}{l}11 \\
11\end{array}$ & $\begin{array}{r}10 \\
9\end{array}$ & $\begin{array}{l}\mathrm{C} \\
\mathrm{C}\end{array}$ & & \\
\hline WATSON12 & 0 & 31 & 12 & 13 & 12 & C & $6 E-09$ & $0.9025-08$ \\
\hline $\begin{array}{l}\text { WATSON20 } \\
\text { CHESQD8 } \\
\text { CHEBQU8 }\end{array}$ & $\begin{array}{l}0 \\
0 \\
1\end{array}$ & $\begin{array}{r}31 \\
8 \\
8\end{array}$ & $\begin{array}{r}20 \\
8 \\
8\end{array}$ & $\begin{array}{l}10 \\
27 \\
86\end{array}$ & $\begin{array}{l}10 \\
17 \\
60\end{array}$ & $\begin{array}{l}\mathrm{C} \\
\mathrm{C} \\
\mathrm{C}\end{array}$ & $\begin{array}{l}0.152 E-14 \\
0.176 \mathrm{E}-02 \\
0.176 E-02\end{array}$ & $\begin{array}{l}0.8 \\
0.2 \\
0.5\end{array}$ \\
\hline $\begin{array}{l}\text { BROWN } \\
\text { BROWN }\end{array}$ & $\begin{array}{l}0 \\
1\end{array}$ & 20 & 4 & $\begin{array}{l}22 \\
23\end{array}$ & $\begin{array}{l}16 \\
19\end{array}$ & C & & $\begin{array}{l}0.149 E-07 \\
0.486 E-07\end{array}$ \\
\hline BRCIN & 2 & 20 & 4 & 32 & 26 & C & $0.429 E+05$ & $0.856 E-08$ \\
\hline BARD & 0 & 15 & 3 & 6 & 6 & C & 0.411 & -07 \\
\hline $\begin{array}{l}\text { BARD } \\
\text { BAX̃̄D }\end{array}$ & $\begin{array}{l}1 \\
2\end{array}$ & $\begin{array}{l}15 \\
15\end{array}$ & $\begin{array}{l}3 \\
3\end{array}$ & $\begin{array}{l}42 \\
21\end{array}$ & $\begin{array}{r}28 \\
9\end{array}$ & $\begin{array}{l}\text { C } \\
\text { C }\end{array}$ & $\begin{array}{l}+01 \\
i+01\end{array}$ & $\begin{array}{l}-07 \\
-07\end{array}$ \\
\hline JENNR & 0 & 10 & 2 & 15 & 12 & C & $0.622 \mathrm{E}+02$ & $E-08$ \\
\hline & $\begin{array}{l}0 \\
1\end{array}$ & $\begin{array}{l}11 \\
11\end{array}$ & $\begin{array}{l}4 \\
4\end{array}$ & $\begin{array}{r}11 \\
163\end{array}$ & $\begin{array}{l}10 \\
90\end{array}$ & $\begin{array}{l}\text { C } \\
\text { C }\end{array}$ & $\begin{array}{l}0.154 \mathrm{E}-03 \\
0.514 \mathrm{E}-03\end{array}$ & $\begin{array}{l}0.7 \\
0.7\end{array}$ \\
\hline $\begin{array}{l}\text { KOWALIK } \\
\text { OSBORNE } 1\end{array}$ & $\begin{array}{l}2 \\
0\end{array}$ & $\begin{array}{l}11 \\
33\end{array}$ & 4 & $\begin{array}{l}81 \\
23\end{array}$ & $\begin{array}{l}61 \\
19\end{array}$ & $\begin{array}{l}\text { C } \\
\text { C }\end{array}$ & $\begin{array}{l}0.154 \mathrm{E}-03 \\
0.273 \mathrm{E}-04\end{array}$ & $\begin{array}{l}0.563 E-07 \\
0.645 E-08\end{array}$ \\
\hline & 0 & 65 & & 17 & 16 & C & $0.201 E-01$ & $0.183 E-07$ \\
\hline OSBORNE2 & 1 & 65 & 11 & 28 & 12 & C & $0.895 E+00$ & $1 E-07$ \\
\hline MADSEN & 0 & 3 & 2 & 11 & 11 & C & & $S E-07$ \\
\hline & 1 & 3 & 2 & 12 & 12 & C & $0.387 E+00$ & $0.185 E-07$ \\
\hline $\begin{array}{l}\text { MADSEN } \\
\text { MEYER }\end{array}$ & $\begin{array}{l}2 \\
0\end{array}$ & $\begin{array}{r}3 \\
16\end{array}$ & $\begin{array}{l}2 \\
3\end{array}$ & $\begin{array}{r}21 \\
281\end{array}$ & $\begin{array}{r}20 \\
175\end{array}$ & $\begin{array}{l}\text { C } \\
\text { C }\end{array}$ & $\begin{array}{l}0.387 E+00 \\
0.440 E+02\end{array}$ & $\begin{array}{l}0.901 E-08 \\
0.244 E-11\end{array}$ \\
\hline
\end{tabular}


Trblo III

Soas Moodefault Test Runs

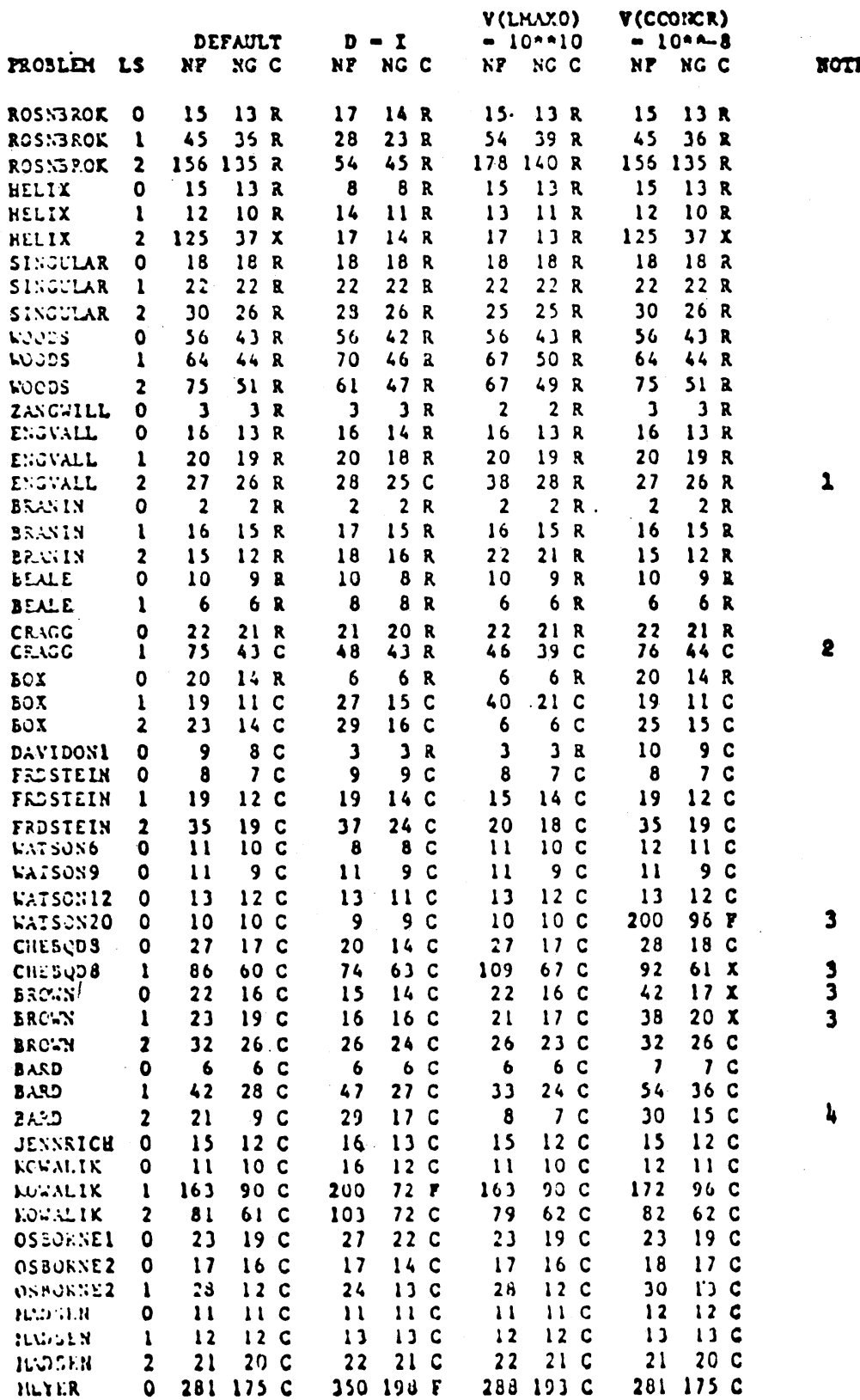


Notes on Table III.

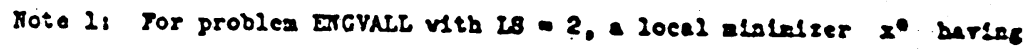
$f\left(x^{\circ}\right)=56.1$ vas found in the D I I ro.

Note 21 Tor problem CRACG vith is - 1, a alffereot local alolalser $x^{\circ}$ one haylng $f\left(x^{\circ}\right)-249$, vas found in the v(Luxs) - 100010 rwo tha in tre DEFAULT run.

Noto 3i Por probleme KATSON20, CHZDQDO, and EATM, a cosine converceser tolerance of $10^{-8}$ eppears too tlght for the double-preclalod erfitwetse of as IBM 370 computer. X-convergence 110 not occur on vatscrs $20^{\circ}$ because ode as tre $x$ components hovered about zero. The sun vltb V(CCOnCR) - 1000-8 acbleree $f(x)=6.46 \times 10^{-18}$ on thle problea land bad $f(x)=6.53 \times 10^{-18}$ e.ter 20 suction and 26 gradient evaluatlons).

Note 4 , For problem BARD vith LS - 2, the D. I rus sound the solurloc obtalned 10 the DEFAURT run vitb is - 0 .

Tablo IV sumarlzes test rune vith three varlante of IL2s02, al of velet used the default cholce of $b_{k}$ and the same IV and $V$ laputs as rere used for Table II. The column headed PUTy cll shov what happens ig the auesanted acse

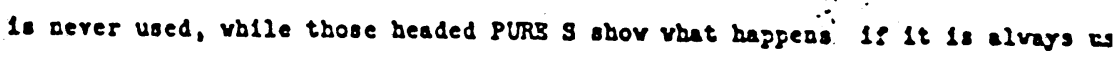
(after the slrot lteration). Finally, the coluane headed ro cizrne gire 2tog

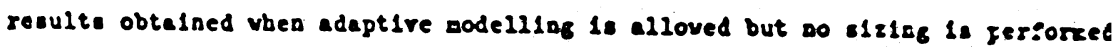
We seel that rable IV makes a good case for the use os adeptire sodelilec vel - Llas ln ML2sOL. 
Tatle IV

Varlation:; on NLREOL

\begin{tabular}{|c|c|c|c|c|c|c|c|c|c|c|c|c|c|c|}
\hline \multirow[b]{2}{*}{ PROBLEM } & \multirow[b]{2}{*}{ LS } & \multicolumn{3}{|c|}{ DEFAULI } & \multicolumn{3}{|c|}{ PURE GN } & \multicolumn{3}{|c|}{ PURE S } & \multicolumn{3}{|c|}{ NO SIZING } & \multirow[b]{2}{*}{ BOTX } \\
\hline & & $\mathbf{N F}$ & NG & & NF & NG & & NF & NG & C & NF & NG & C & \\
\hline ROSNB ROK & 0 & 15 & 13 & $\mathbf{R}$ & 20 & 16 & $\mathbf{R}$ & 24 & 21 & $\mathbf{R}$ & 20 & 16 & $\mathbf{R}$ & \\
\hline KU:Z:it KuK & 1 & 45 & 36 & 4 & 38 & 33 & $\mathbf{R}$ & 63 & 33 & R & 43 & 35 & R & \\
\hline ROSIBROK & 2 & 156 & 135 & $\mathbf{R}$ & 113 & 103 & $\mathbf{R}$ & 200 & 45 & $\boldsymbol{F}$ & 122 & 111 & $\mathbf{R}$ & \\
\hline HELIX & 0 & 15 & 13 & $\mathbf{R}$ & 10 & 10 & $\mathbf{R}$ & 22 & 19 & $\mathbf{R}$ & 10 & 10 & $\mathbf{R}$ & \\
\hline HELIX & 1 & 12 & 10 & $\mathbf{R}$ & 12 & 11 & $\mathbf{R}$ & 25 & 16 & $\mathbf{R}$ & 13 & 10 & $\mathbf{R}$ & \\
\hline HEL IX & 2 & 125 & 37 & $x$ & 16 & 14 & $\mathbf{R}$ & 38 & 23 & $\mathbf{R}$ & 140 & 39 & $x$ & \\
\hline SINGULAR & 0 & 18 & 18 & $\mathbf{R}$ & 18 & 18 & $\mathbf{R}$ & 29 & 29 & $R$ & 18 & 18 & $\mathbf{R}$ & \\
\hline SINGLLAR & 1 & 22 & 22 & $\mathbf{R}$ & 22 & 22 & $\mathbf{R}$ & 35 & 35 & $\mathbf{R}$ & 22 & 22 & $\mathbf{R}$ & \\
\hline SIIGLLAR & 2 & 30 & 26 & $\mathbf{R}$ & 30 & 26 & $\mathbf{R}$ & 43 & 42 & $\mathbf{R}$ & 30 & 26 & R & \\
\hline $\begin{array}{l}\text { WOODS } \\
\text { WODS }\end{array}$ & 0 & 56 & 43 & $\mathbf{R}$ & 77 & 67 & $R$ & 47 & 34 & $\mathbf{R}$ & 80 & 50 & $R$ & \\
\hline WOODS & 1 & 64 & 44 & $\mathbf{R}$ & 30 & 65 & $\mathbf{R}$ & 47 & 40 & $\mathbf{R}$ & 116 & 67 & $\mathbf{R}$ & \\
\hline WOODS & 2 & 75 & 51 & $\mathbf{R}$ & 74 & 55 & $\mathbf{R}$ & 62 & 47 & $\mathbf{R}$ & 80 & 58 & $\mathbf{R}$ & \\
\hline ZAVGHILL & 0 & 3 & 3 & $\mathbf{R}$ & 3 & 3 & $\mathbf{R}$ & 3 & 3 & $\mathbf{R}$ & 3 & 3 & $\mathbf{R}$ & \\
\hline E:GGVALL & 0 & 16 & 13 & $\mathbf{R}$ & 15 & 13 & $\mathbf{R}$ & 19 & 17 & $\mathbf{R}$ & 16 & 13 & $\mathbf{R}$ & \\
\hline E::GVALL & 1 & 20 & 19 & $\mathbf{R}$ & 14 & 14 & $\mathbf{R}$ & 25 & 22 & $\mathbf{R}$ & 18 & 17 & $\mathbf{R}$ & \\
\hline ENGVALL & 2 & 27 & 26 & $\mathbf{R}$ & 28 & 27 & $\mathbf{R}$ & 38 & 36 & $\mathbf{R}$ & 27 & 26 & $\mathbf{R}$ & \\
\hline BRALIN & 0 & 2 & 2 & $\mathbf{R}$ & 2 & 2 & R & 2 & 2 & $\mathbf{R}$ & 2 & 2 & $\mathbf{R}$ & \\
\hline BRAN IN & 1 & 16 & 15 & $\mathbf{R}$ & 16 & 15 & $\mathbf{R}$ & 24 & 23 & $\mathbf{R}$ & 17 & 15 & $\mathbf{R}$ & \\
\hline $\begin{array}{l}\text { BRANIN } \\
\text { BEALE }\end{array}$ & $\begin{array}{l}2 \\
0\end{array}$ & 15 & 12 & $\mathbf{R}$ & 15 & 12 & R & 38 & 35 & $R$ & 15 & 12 & R & \\
\hline BEALE & 1 & 6 & $\begin{array}{l}y \\
6\end{array}$ & $\begin{array}{l}\mathbf{R} \\
\mathbf{R}\end{array}$ & $\begin{array}{r}10 \\
6\end{array}$ & $\begin{array}{l}9 \\
6\end{array}$ & $\begin{array}{l}\mathbf{R} \\
\mathbf{R}\end{array}$ & $\begin{array}{l}19 \\
14\end{array}$ & $\begin{array}{l}14 \\
13\end{array}$ & $\begin{array}{l}R \\
R\end{array}$ & $\begin{array}{r}10 \\
6\end{array}$ & $\begin{array}{l}9 \\
6\end{array}$ & $\begin{array}{l}\mathbf{R} \\
\mathbf{R}\end{array}$ & \\
\hline CRAGG & 0 & 22 & 21 & $\mathbf{R}$ & 21 & 20 & $\mathbf{R}$ & 38 & 35 & $\mathbf{R}$ & 22 & 21 & $\mathbf{R}$ & 1 \\
\hline CRAGG & 1 & 75 & 43 & C & 153 & 100 & C & 200 & 120 & C & 179 & 86 & C & \\
\hline BOX & 0 & 20 & 16 & $\mathbf{R}$ & 22 & 16 & $\mathbf{R}$ & 46 & 26 & $\mathbf{R}$ & 19 & 14 & $\mathbf{R}$ & \\
\hline BOX & 1 & 19 & 11 & C & 20 & 12 & C & 61 & 52 & R & 20 & 12 & C & \\
\hline BOX & 2 & 23 & 14 & C & 25 & 16 & C & 38 & 24 & C & 25 & 16 & C & \\
\hline DAVIDORI & 0 & 9 & 8 & C & 9 & 8 & C & 9 & 8 & C & 9 & 8 & C & \\
\hline ERUSTEIN & 0 & 8 & 7 & C & 26 & 15 & C & 8 & 8 & C & 8 & 7 & C & \\
\hline FRDSTEIN & 1 & 19 & 12 & C & 37 & 22 & C & 24 & 18 & C & 20 & 13 & C & \\
\hline FRDSTEIN & 2 & 35 & 19 & C & 46 & 22 & C & 44 & 29 & C & 36 & 20 & C & \\
\hline $\begin{array}{l}\text { WAISON6 } \\
\text { WATSO:i9 }\end{array}$ & $\begin{array}{l}0 \\
0\end{array}$ & 11 & $\begin{array}{r}10 \\
9\end{array}$ & $\begin{array}{l}\text { C } \\
\text { C }\end{array}$ & $\begin{array}{l}13 \\
11\end{array}$ & $\begin{array}{r}12 \\
9\end{array}$ & $\begin{array}{l}\text { C } \\
\text { C }\end{array}$ & $\begin{array}{l}15 \\
21\end{array}$ & $\begin{array}{l}11 \\
14\end{array}$ & $\begin{array}{l}c \\
C\end{array}$ & $\begin{array}{l}12 \\
12\end{array}$ & $\begin{array}{l}11 \\
10\end{array}$ & C & \\
\hline WATSO:1 2 & 0 & 13 & 12 & C & 13 & 12 & C & 21 & 17 & C & 14 & 11 & C & \\
\hline $\begin{array}{l}\text { WAISO:: } 20 \\
\text { CHEBQD } 8\end{array}$ & $\begin{array}{l}0 \\
0\end{array}$ & $\begin{array}{l}10 \\
27\end{array}$ & $\begin{array}{l}10 \\
17\end{array}$ & $\begin{array}{l}\text { C } \\
\text { C }\end{array}$ & $\begin{array}{l}10 \\
43\end{array}$ & $\begin{array}{l}10 \\
29\end{array}$ & $\begin{array}{l}\text { C } \\
\text { C }\end{array}$ & $\begin{array}{l}16 \\
22\end{array}$ & $\begin{array}{l}15 \\
18\end{array}$ & $\begin{array}{l}\text { C } \\
\text { C }\end{array}$ & $\begin{array}{l}10 \\
25\end{array}$ & $\begin{array}{l}10 \\
16\end{array}$ & $\begin{array}{l}\text { C } \\
\text { C }\end{array}$ & \\
\hline СНЕВ२О & 1 & 86 & 60 & C & 118 & 78 & C & 131 & 90 & C & 147 & 98 & C & \\
\hline $\begin{array}{l}\text { BRUWY } \\
\text { BROAN }\end{array}$ & $\begin{array}{l}0 \\
1\end{array}$ & $\begin{array}{l}22 \\
23\end{array}$ & $\begin{array}{l}16 \\
19\end{array}$ & C & $\begin{array}{l}128 \\
153\end{array}$ & $\begin{array}{l}84 \\
89\end{array}$ & $\begin{array}{l}\text { C } \\
\text { C }\end{array}$ & $\begin{array}{l}19 \\
24\end{array}$ & $\begin{array}{l}17 \\
23\end{array}$ & C & $\begin{array}{r}30 \\
171\end{array}$ & $\begin{array}{l}21 \\
86\end{array}$ & $\begin{array}{l}\text { C } \\
\text { C }\end{array}$ & \\
\hline BROWX & 2 & 32 & 26 & C & 82 & 59 & C & 33 & 28 & C & 200 & 91 & $\mathbf{F}$ & \\
\hline $\begin{array}{l}\text { BARD } \\
\text { BARD }\end{array}$ & $\begin{array}{l}0 \\
1\end{array}$ & $\begin{array}{r}6 \\
42\end{array}$ & $\begin{array}{r}6 \\
28\end{array}$ & C & $\begin{array}{r}6 \\
42\end{array}$ & $\begin{array}{r}6 \\
28\end{array}$ & $\begin{array}{l}\text { C } \\
\text { C }\end{array}$ & $\begin{array}{l}10 \\
7.6\end{array}$ & $\begin{array}{l}10 \\
34\end{array}$ & $\begin{array}{l}\text { C } \\
\text { C }\end{array}$ & $\begin{array}{r}6 \\
43\end{array}$ & $\begin{array}{r}6 \\
29\end{array}$ & C & 2 \\
\hline BARD & 2. & 21 & 9 & C & 21 & 9 & C & 83 & 26 & C & 21 & 9 & C & 2 \\
\hline $\begin{array}{l}\text { JE::IRICH } \\
\text { KÖNLIK }\end{array}$ & $\begin{array}{l}0 \\
0\end{array}$ & $\begin{array}{l}15 \\
11\end{array}$ & $\begin{array}{l}12 \\
10\end{array}$ & $\begin{array}{l}\text { C } \\
\text { C }\end{array}$ & $\begin{array}{l}22 \\
26\end{array}$ & $\begin{array}{l}12 \\
25\end{array}$ & $\begin{array}{l}\text { C } \\
\text { C }\end{array}$ & $\begin{array}{l}13 \\
20\end{array}$ & $\begin{array}{l}12 \\
15\end{array}$ & C & $\begin{array}{l}17 \\
12\end{array}$ & $\begin{array}{l}13 \\
11\end{array}$ & C & \\
\hline KoGial IK & 1 & 163 & 90 & C & 108 & 78 & C & 200 & 63 & $\mathbf{P}$ & 99 & 73 & C & \\
\hline $\begin{array}{l}\text { KOWALIK } \\
\text { OSSORIEL }\end{array}$ & $\begin{array}{l}2 \\
0\end{array}$ & $\begin{array}{l}81 \\
23\end{array}$ & $\begin{array}{l}61 \\
19\end{array}$ & $\begin{array}{l}\text { C } \\
\text { C }\end{array}$ & $\begin{array}{r}109 \\
17\end{array}$ & $\begin{array}{l}85 \\
15\end{array}$ & $\begin{array}{l}\text { C } \\
\text { C }\end{array}$ & $\begin{array}{r}200 \\
34\end{array}$ & $\begin{array}{l}76 \\
31\end{array}$ & $\begin{array}{l}F \\
C\end{array}$ & $\begin{array}{r}184 \\
17\end{array}$ & $\begin{array}{r}151 \\
15\end{array}$ & I & \\
\hline OSBOR:EE 2 & 0 & 17 & 16 & C & 17 & 15 & C & 16 & 15 & C & 17 & 16 & C & \\
\hline $\begin{array}{l}\text { OSBUR:IE2 } \\
\text { MHOSEN }\end{array}$ & $\begin{array}{l}1 \\
0\end{array}$ & $\begin{array}{l}28 \\
11\end{array}$ & $\begin{array}{l}12 \\
11\end{array}$ & $\begin{array}{l}\text { C } \\
\text { C }\end{array}$ & $\begin{array}{l}14 \\
45\end{array}$ & $\begin{array}{l}12 \\
45\end{array}$ & $\begin{array}{l}\text { C } \\
\text { C }\end{array}$ & $\begin{array}{l}18 \\
12\end{array}$ & $\begin{array}{l}10 \\
12\end{array}$ & $\begin{array}{l}\text { C } \\
\text { C }\end{array}$ & $\begin{array}{l}30 \\
13\end{array}$ & $\begin{array}{l}14 \\
13\end{array}$ & $\begin{array}{l}\text { C } \\
\text { C }\end{array}$ & \\
\hline MADSEN & 1 & 12 & 12 & C & 42 & 42 & C & 16 & 16 & C & 14 & 14 & C & \\
\hline $\begin{array}{l}\text { MADSEN } \\
\text { MEYER }\end{array}$ & $\begin{array}{l}2 \\
0\end{array}$ & $\begin{array}{r}21 \\
281\end{array}$ & $\begin{array}{r}20 \\
175\end{array}$ & $\begin{array}{l}\text { C } \\
\text { C }\end{array}$ & $\begin{array}{r}56 \\
282\end{array}$ & $\begin{array}{r}55 \\
183\end{array}$ & $\begin{array}{l}\text { C } \\
\text { C }\end{array}$ & $\begin{array}{r}23 \\
321\end{array}$ & $\begin{array}{r}23 \\
183\end{array}$ & $\begin{array}{l}\text { C } \\
\text { C }\end{array}$ & $\begin{array}{r}23 \\
189\end{array}$ & $\begin{array}{r}21 \\
138\end{array}$ & C & \\
\hline
\end{tabular}




\section{Notes on Table IV}

Note 1: Each of the runs listed for problem CRAG vitb is $=1$ found a different local minimizer $x^{*}$. The DEFAULT run found $f\left(x^{*}\right)=59.2$; the PURE GN run found $f\left(x^{*}\right)=9.98 \times 10^{4}$; the PURE S run found $f\left(x^{*}\right)=4.37$; and the No SIZING run found $f\left(x^{*}\right)=1.11 \times 10^{4}$.

Note 2: While the other runs of problea BARD found the same local minimizer as the corresponding DEFAULT run, the PUFE $S$ runs gave different results. For $I S=1$, the PURE S run found $f\left(x^{\circ}\right)=4.11 \times 10^{-3}$ (as did the DefaUlT run with is $=0$ ), and for is -2 , it found $f\left(x^{\circ}\right)=8.45$. 


\section{FEFERETCES}

BhPD. T. (1970), Cosparlsod of eredlent methods for tbe solution of nonilnear peraceter estlizat1on problems. SIAN J. iumer. Anal. T, 22. 157-186.

BA3., Y. (29:4), Nonilnear Pareseter Estimat1on, Acaderle Press, Rev York.

EEirs, E.M. (1958), Co an 1terntive gethod for finding a local alni=um of a furction of aore than one variable. Tech. Rept. No. 25. Statistical Technlques Fesearch Group, Princeton Unlversity, Princcton, liew Jersey.

EETS. J.T. (1976), Solving the nonlinear lenst square frobles: Application of a seneral eethod. J. Opttmization Theory Arrl. 18, pp. 469-484.

Box, KJ. (1956). A ccaparison of several current optinlzation Eethoda and the use of trarsformatloss in constrained probieas. Comput. J. 9, pp. 67-77.

BRAFIX, F.g. (1971), Wldely convergent method for flnding Eultiple solutions of - Leultanecus nonlinear equations. IBM J. Res. Develog. 16, pp. 504-522.

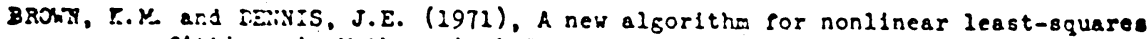
curve ritting. In Nishezatical Sortware edited by John R. Rlce, Acaderic Press, Hew York. pp. 391-390.

COLIILIS, A. 3. ( 1968 ), A comparative study oi nonlinear programing codeB. IBM Nev York Selentific Center Tech. Pept. Ho. 320-2349.

CRASE, E.E. end LEVY, A.V. (1969), Study on a supermemory gradient method for

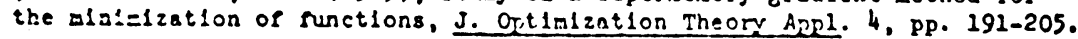

chrax:i, W. C. (1976), Nev least-square algorithms, J. Ontimlzation Theory Appl. 18, Fp. 187-197.

Eminj, J.E. (1973), Scze cosputational technlques for nonlinear least squares frotiez. In Numarlcal Sclutiono or Systcms of innlinenr Fquntions edited by C.D. Eyrne ard C.A. Hall, Academic Press, Hew York.

EETIS, J.E. (1977), Norilinear least squares and equations. In the State of the A-t of Pusericsl Aralysis edited by D. Jacobs. Academic Press, London

DExis, J.I. asd :!OFE. J.J. (1977), Quas1-Newton methods, mot1ration and theory. S.h. F.e. 19. Fp. 46-89.

Manis, J.E. and WEISCH. R.E. (1978). Technlques for nonlinesr least squares and rotust regression. Ccris. Stet1st. BT. pp. 345-359.

Eovail, J.L. (1966), Numerlcal elgorlth for solving over-determlned systems of nonlinear equations. NASA docwaent NTO-35600.

FEC:s, R. (1965), Function minimization vithout evaluating derlvatives-a reviev. Cosiut. J. 8, pp. 33-41. 
METCEER, R. (1971), A mod1fled Marquardt subroutine por soollnear least oguarea, A.z.R.z. Rarvell report p6799.

METCHER, R. and PARELL, M.J.D. (1963), A raplaly contergest desces: ze: 20 d for minleliation. Co-mit. J. 6, pp. 163-168.

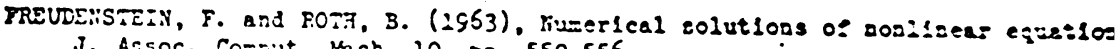
J. Assoc. Co-.iut. Mach. 10, F2. 550-556.

OAY, D. (1979), Cozputing optinal locally constralned steps, lo preparetion

GILL, P.E. and MJPSAY, W. (1976), Nonlldear least squares and cos:i=eeriy

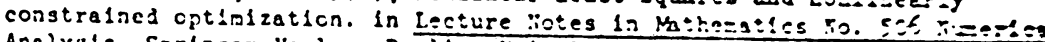
Annlyals. Sprineer-Vcriag, Berlin, Heleeltere, erid lied Yotz.

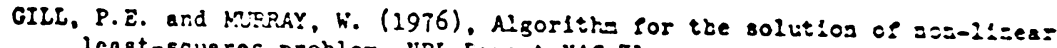
least-squareg problers. IIPL Feport HAC 71 .

COLUB, G.R. (1969). Natrix decorpositions and statistical calculatioss. Is Statistlcal Computation edited by R.C. Mliton and J.A. Belier, Acasefie Preac, liew York, pp. 365-397.

JENNRICH, R.I. and SA:PSOH, P.F. (1958). ARpl1cation of step-vlee regressico to nonlincar estimation. Technosetr1ce 10, pp. 63-72.

KOWALIK, J.S. and OSBOR:IE, M.R. (1958), Vrthods for Inconstrairas: Cntlalzation Probiems, Arerl can Elocvler. liev York.

MEYER, R.R. (1970), Theoretical and corputational asfects of condi=en regress: In lionlinear Proern-ming edited by J.B. Posen, 0.L. Magasarias, C=1 If S: Acaderale Press, New Yo:k.

MORE, J.J. (1978), The Levenberg-!erquardt algoritha: 10plesestat:0s a:1 iteo:J

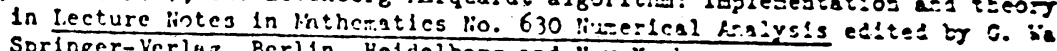
Springer-VerluB, Berlin, Heldelbere and lled York.

MORE. J.J. (1979), Implezentation and Testing of Oftlalzation Sortvare, Lupp Report 79/IAA , University of Carbridge, UK.

OREN, 3.3. (1973). Self-ccallne varlabia netrle aleorlitso vlthous ilse seazeb for unconstralned minimization. Mpth. Cozput. 27, Pp. 873-235.

OSBORTE, M.R. (1972), SOme aspects of nonllnear least squares calesla:10ss.

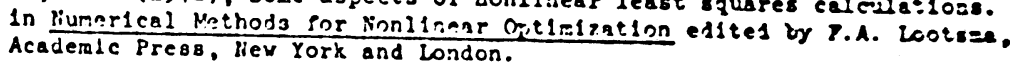

POFELL, M.J.D. (1962), An Iterative method for flnding statloasty ralies os a runction of several varlables. Comput. J. 5. pp. 147-151.

POWELL, K.J.D. (1970), A FCRTRAil subroutine for uaconstralnec eli=l=12a::cz, requiring rirst derlvatives of the objective runction. Refort A. E. R.E. Rarwell, Oxfordshlte, Enelard. 
P:A.: J. J. (1977), when to stop a quasi-Newton search for a maximum 11kellbood estiasta. Working paper 77-16, Harvard Business School, Soldiers Field Rd., Bostc Mass.

PAO, C.P. (1955), Lineqr Statistical Inference and Its Applications, John

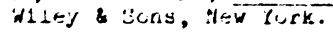

R.CSESPROK, R.H. (1960), An automatic method for finding the greatest or least value of a function. Comput. J. 3, pp. 175-184.

WEDIN, P-A. (1972), (1974a), The non-linear least squares problem from a numerical point of view, I and II. Lund. Univ. Computer Sci. Tech. Repts.

WEDIR, P-A. (1974b), On surface dependent propertles of methods for separable risn-11near least squares problems. Inst. Pbr tellumpad matematik, Box 5073 Stockholm 5, ITM Arbetsrapport nr. 23.

WEDIN, P-A. (1974C), On the Causs-Newton method for the non-11near least squares problem. Inst. för tellkmped matemat1k, Box 5073 stockholm 5, ITM Arbetsrapport nr. 24.

ZANGWILL, Y.J. (1967), Nonlinear programming via penalty runctions. Management Sc1. 13, pp. $344-358$. 


$$
\text { n, }
$$


A $P$ I X D I.

NL2SOL Usage Sunnary

\section{Contents}

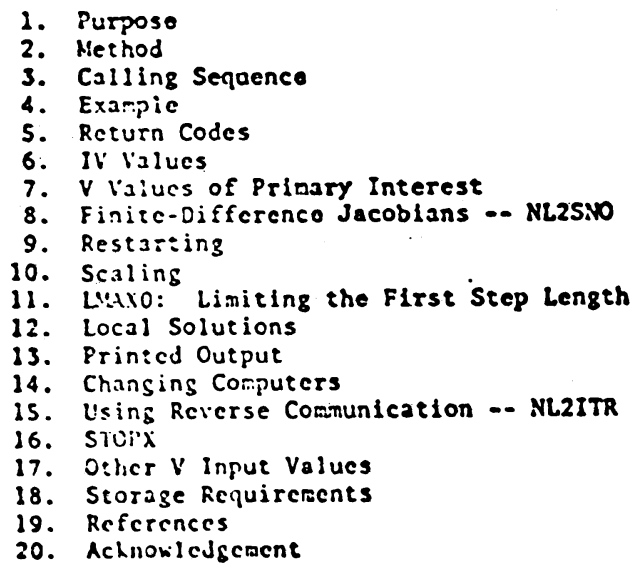

1. Purpose

Given a continuously differentable function (rosidual vector) $R(x)=\left(R_{1}(x), R_{2}(x), \ldots, R_{n}(x)\right)^{T}$ of $p$ parameters $x=\left(x_{1}, x_{2}, \ldots, x_{p}\right)^{T}$ NL2SOL attempts to find a parameter vector $x$ * which minimizes the sun-ofsquares function $f(x)=\frac{1}{2} \sum_{1-1}^{n} R_{1}(x)^{2}$.

\section{Yeshod}

Reference 1 explatins the algorlthm reallzed by NE2SOL in detall. The algorfthx a =ounts in part to a variation on Newton's wethod In which part of the llessian eatrix is computed exactly and part is approximated by a sccsat (quas:-Neuton) updating method. Once the 1terates come sufficiently clese to a (local) solution, they usually converge quite rapldiy. To proes:e convergence fron poor starting guesses. NL2SUL uses a model/trustregion technique along with an adaptive cholce of the model Hessian. Conseguentiy, the alcorlthm sumetlmes reduces to a Causs-ivicton or Levenbersfiarquarde nethod. On large-residual problens (in which $F\left(x^{\star}\right)$ is large),

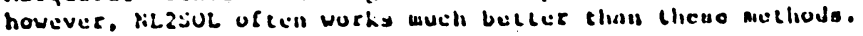

\section{Calling Seguence}

CALL NLZSULLS, P, X, CALCK, CAI.C.J. IV, V, UIPARM, UKPARU, UKPNRHI) 
Motel In the double-precision version of rizsol, all quantitles tered REAL below ate actUally DOUBLE PRECISION.

$X$ (Input INTECER) is the number of components in the residusl vector

8 (Input INTEGER) 18 the nut.ber of paraseters on whlch 2 depents.

$X$ (I/O REAL array of length $P$ ) on Input is an Initlal guess at the desired solution $x^{\star}$. then :L2SOL returns after converging or reachlng the 1teration linit (1.e., returns with IV(1) - 3. 4. S. 6 , or 8 ), $X$ containg the best pararcter escleate found.

CArcR (input subroutine) computes the residual vector $R-Z(X)$ visez Invoked by:

CALL CALCR (N, P, X, NF, R, UIPARY, LRPAEY, UEPAEY)

When CAICR is called, Ne 1s the Invocation count for CALCR; ie is Included for possible use with CAlCJ. If $X$ is out of bounds (e. If $R(X)$ would overf low), then CALCR should set SP to 0 , visich vil cause a shorter step to be attenpted. CALCR should not chasge $\$$, I or $X$ and should bc dcclared EXTERliAl in the calling progras. 2 chould be declared REAL R(ii).

CAras (Input subroutine) computes the Jacoblan matrlx $J-J(x)$ of E1rst partiole. $J_{1 j}-\frac{\partial R_{1}}{\partial x_{j}}(x)$, when Invoked by:

CALL CALCJ (N, P, X, NF, J, UIPARY, URPAPM, UFPARY)

when CAlCJ 18 cnlled, NF 1 the invocation count for CALCR at the time when $R(X)$ was evaluated. Except when $J$ is restorel after. covariance matrix has been cosputed with IV(COVREP) - 1 or 2 (see 56), the $X$ passed to CALCJ is the one passed to CALCR oz eltie: Its most recent invocation or the one prlor to 1t. Thus if ciien eaves Inecrmadiace regulta for usc by CALCJ. then le le posalbie to tell from if whether they are valld for the current $x$ lor itich copy is valid if two are kept). If $J$ cannot be cosputed at $x$, thes CALCJ should set RF to 0 . CALCJ should dot chanze $X, P$, o: $I$ a $=d$ should be declared ExTLi:inl in the calling prograa. J shovid te declared KEAL $J(i, P)$.

IV ( $1 / 0$ INTEGER array of length $P+60$ ) on loput contains certalo values (such as $11 \mathrm{mits}$ on the number of leerations and calls or CALCR) that control the bchavior of HL2SOL and on output contasne varlous counts and other lices of interest: see 555 and 6 . If IV(1) - 0 on 1nput, then default values are supplied for the inpue corponents of both $I V$ and $V$. The caller may supply concesail:

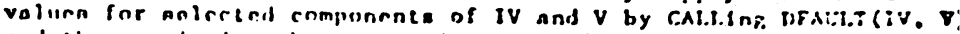
and then assigning the approprlate nondefault values before callia NL2SOL.

V (I/O REAL array of Jength $96+H \cdot(P+3)+P \cdot(7 P+43) / 2)$ on Inpute conentua curtalin valuen (uuch na convergence colerancen) elias 
control the behavior of NL2SOL and on output contains various items of interest (such as $F(X)$ and $R(X)$ ): see $\$ \xi 7$ and 17 .

OLPARY (I:itrer.R artay of length determinad by tho callor) 10 paoned without change to CALCR and CALCJ and may be used by them in any way that the caller may find cunvenient.

URPAPM (REAL artay of 1enp,th determined by the caller), 11ke UIPARM, is passed without change to CALCR and CALCJ.

UPPARY (subroutine), like UIPARY, is passed without change to CALCR and CALCJ. If there is no need for such a subroutine, then on many -ystems $1 t$ sufflces to pass an arbitrary variable or constant for UFPARY. But if an actual subroutine 18 passed, then 1 t must be declared EXTERNAL in the calling program.

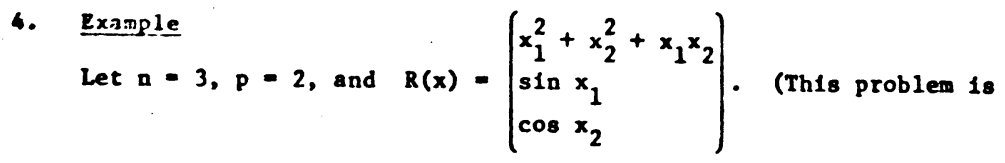

due to Madsen, Reference 3.$)$ The following FORTRAN code minimizes $F(x)=\frac{1}{2} R(x)^{T} R(x)$, starting from the lnitial guess $(3,1)^{T}$, using a singleprecision version of NL2SOL.

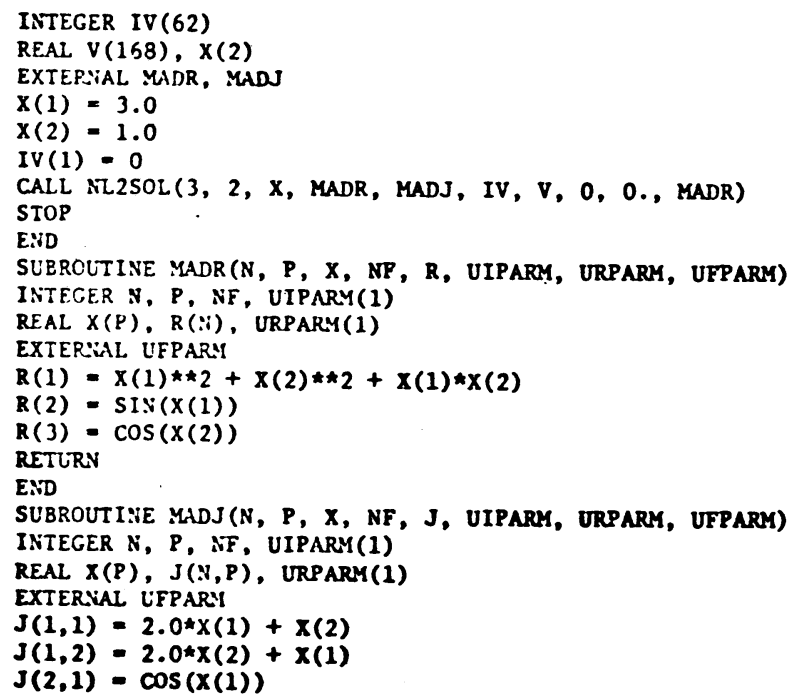




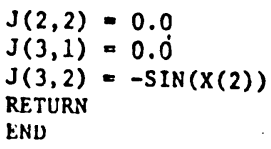

The main program above passes MADR as CALCR and MADJ as CALCJ. Since no use is made of UIPARY, URPARY, Or UFFARY, zeroes are passed for UIPARY and URPAR' and MUDR is passed for UFPAKI.

When the above is executed, NL2SOL prints the initial $X$ vector, a summary of the iterations performed, the final $X$ vector, and some statistics (including the $f$ inal $F(X)$ and a covarlance matrix). If REAL is changed to DOUBLE PRF.CISION and the above is run on an IBM 370 computer, then NL2SOL. reports varlabllity convergence (IV(1) = 6-- see 55 ) after 7 calls on CALCR and CALCJ and returns $X(1)=-0.156234, X(2)=0.698698$, and $F(X)=0.386616$.

In this example, it is possible to obtain a slightly smaller value of $F(x)$ by decreasing the variability convergence tolerance from 1 ts default value of $10^{-4}$. If the statement IV(1) = 0 in the main program is replaced by CALL DFAULT (IV, V) $V(42)=0.0$

then variablitty convergence testing is turned off. When this modified version of the example 18 run on an IBM 370 with REAL changed to DOUBLE PRECISION, NL2SOL reports cosine convergence (IV(1) = 4) after 11 call: On CALCR and CALCJ and returns $X(1)=-0.155437, X(2)=0.694564$, and
$F(X)=0.386600$.

\section{Return Codes}

When NL2SOL returns, IV(1) contains one of the following return codes:

3 - $X$ convergence: see $V(X C O N C R)$ in 57 .

4 - cosine convergence: see $V(C C O N C R)$ in $\$ 7$.

5 - residual convergence: see $V(R C O N C R)$ in 57 .

6 - variability convergence: see $V$ (VCONCR) in 57 .

7 - function evaluation limit reached: see IV(MXFCAL) in $\$ 6$.

8 - Iteration limit reached: see IV(:XITER) in $\$ 6$.

9 - STOPX returned. TRUE. (external interupt): see $\$ 16$.

11 - $F(X)$ overflows at the initial $X$.

12 - bad parameters passed to ASSESS (which should not occur).

13 - $J(X)$ could not be computed (1.e., CALCJ set NF to 0 ).

14 - one of the inequalities $N N \geqslant N \geqslant P \geqslant 1$ is violated. (NN Is only of interest to those who exercise the reverse communication option - see 515.)

15 - NL2SOL was restarted (see 59) with NN, $N$, or P changed.

16 - IV(INITS) is out of range: see 56 .

17 - IV (1) was out of range (1.e., was negative or greater than 10) when NL2SOL was called.

18 or more - V(IV(1)) 18 out of range: see 557 and 17.

Just before in.2sol returns, a brief description of the return code 


\section{1s priated (unless all printing is turned off by IV (PRUNIT) - 0).}

\section{IV Values}

IV Insut Valucs (Supplied by DFAURT)

IV(1)........ IV(1) should have a value between 0 and 10 when NL2SOL 1a called. 0 and 10 both mean that thls is a fresh start; 0 means DFAULT(IV, V) should be Invoked to supply defaule values to the input components of IV and $v$, while 10 means that the caller has already supplied these values. IV(1) Input values beticen 3 and 9 mean that $\mathrm{NL} 2 \mathrm{SOL}$ should restart: see 99. Defoult -10 .

IV(COVRRi)... IV(14) = 1 means print a covarlance matrix at the solution. This natrix is computed as IV (COVREQ) dictates just before a return with IV(1) - 3, 4, 5, or 6 . IV(COVPRT) - 0 means do not print a covariance matrix. Defaule $=1$.

IV(COVREQ)... IV(15) \& 0 means compute a covarlance matrlx fust before a return with IV(1) $=3,4,5$, or 6 . In this case, an approxicate covariance riatrix is obtalncd in one of several ways. Let $k$ - |IV(CONREQ $) \mid$ and let $\sigma-2 F(X) / m x(1, N-P\}$, where $2 F(X)$ is the residual sum of squares. If $k-1$ or 2 , then - finite-difference Hessian approximation $H$ is obtained. If $b$ is positive-definlte (or, for $k$ - 3 , if the Jacobian matrix $J$ - $J(x)$ is nonsingular), then one of the following is computeds

$$
\begin{aligned}
& k=1 \longrightarrow \sigma \cdot H^{-1}\left(J^{T} J\right) H^{-1} \\
& k=2 \longrightarrow \sigma \cdot H^{-1} \\
& k=3 \longrightarrow \sigma \cdot\left(J^{T} J\right)^{-1} .
\end{aligned}
$$

If IV(COVREQ) > 0 , then both function and gradient values (calla on CALCR and CALCJ) are used in corputing $H$ (with stap sizes detcrmined by V(DEI.TAO) -- see 57 ), while if IV (COVRR:Q) $<0$, then only function values (calls on CALCR) are uged (wlth step sizes deternined by $V(D L T F D C)$ ). If IV (COVREQ) - 0 , then no atterpe is tade to conpute a covariance matrix (unless

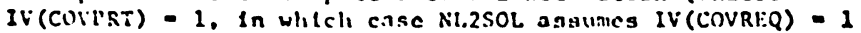
ad ilzsiv assui:es IV (CUNkEQ $)$ - -1). Defaule - 1 .

IV(InTS).... IV(16) tells how the $S$ matrix of Ref. 1 should be Initiallzed: $O$ means set $S$ to 0 and start with the Gauss-Neuton model; 1 and 2 nean that the caller has supplicd the Inletal $S$, otorlng lto lower trlanble row-wise in $V$ starting at $V(P+87)$; IV(INITS) - 1 ecans start vith the Gauss-Newton mudel, whlle IV(INITS) - 2 acans start with the augiented model. Default - 0 .

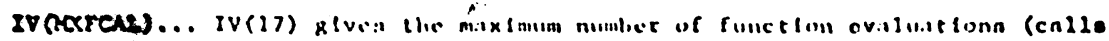
on Cil.ck, excluding thinge used to coinpute llie covardance matrix) allowed. If this number does not suffice, then NL2SUL returns wleis IV(1) - 7. Default - 200.

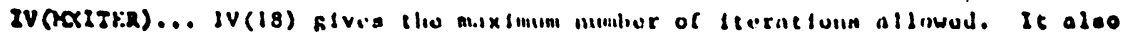
indirectly limbte the number of gradlent evaluacluno fcalle on 
CALCJ, excluding those used to compute the covarsance eatrix) to IV (MXITER) + 1. If IV (.XXIIER) 1terat!oss Lo not surfICe, thes II2SOL returns with IV(1) - 8. DeSaule - 150 .

IV(OUTLE7)... IV(ig) controls the nueber ard leagth of Leescien su=ary lines printed. IV (OUTLEV) - 0 tesas do ros priat ary su=ant

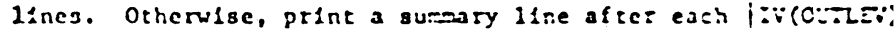

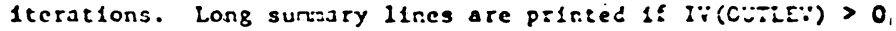
short lines if IV (OUTLEV) < 0 . See $\$ 13$ for sore cetails. Defnule - 1 .

IV(PARPRT)... IV(20) - 1 means print any nonjefault $v$ values or a fresh start or any changed $V$ (Input) values on a restaz:. IV(PARSRT) - 0 means skip thls printing. Desaute - 1.

IV(PRUNIT)... IV(21) is the output un1t nusber on wh1ch ail prla:!=8 is done. IV(?RLRIIT) - 0 seans suppress all p::a:1::0. (Ser:10z IV (PRU::IT) to 0 is the only way to supprces the one-lise teralnation aessage printed before SL2SOL retur=s.) Default - standard output unit (unlt 6 on $=05 t 5 ;$ ste-s); the cefaule for IV(PRUNIT) is actually LDco:i(1): see \$14.

IV(SOLPRT)... IV(22) - 1 r.cans print the $X$ returmed (a!csg $v !$ th the corresponding gradlent and scale vector D). IY(SCiPs:) - 0 wcans skip this printing. Default - 1 .

IV(STATPR)... IV(23) - 1 ceans print sursary statistics upos returaiaz. These conslat of the function value (half the rcsidual se of aquarcs) at $x$, the varfabllity of the last ste? (see V(VEJ::Cs In 57), the number of function and gradlese evaluatless (eall on CALCR and CALCJ respectively, exeliding asy calls used 1= computing the courance), the 2 -nore of the gracies: at $Y$.

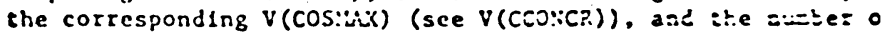
calls (1f positive) on CAiCR and CALCJ used is irjisg to cCs covarlance matrices. IV(STATPR) = 0 means sikip this prictisz Default - 1 .

IV(XopRT).... IV(24) - I weans print the infelal $x$ and scale vector $D$ if this is a fresh start. IV(XOPRT) - 0 means sklp chls prlotis Default - 1 .

IV Qutput Valucs of Primiry Intercyt

IV(1)........ IV (1) 1s the return code: see $\$ 5$.

IV(COVur)... IV(26) tells whether a covariance astrix vas coaputed. If iv(covint) 1o positive. then the lover erlarigle of the covar! ance matrix is stored row-wlse in $v$ starting at $V$ (I: (COirat) :

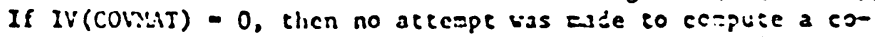

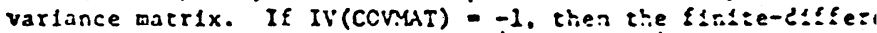

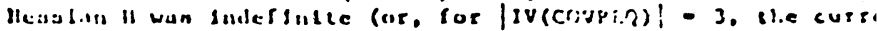
Jacolian matelx is singular; sec IV(CO\%grQ) 2bove). and if IV (conilit) - -2, then a successful finfte-difference step col

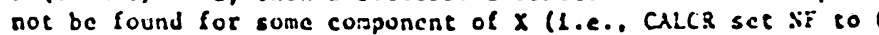
for enclo of (wo erlal nerph). Hute that iv(roividi) is erses

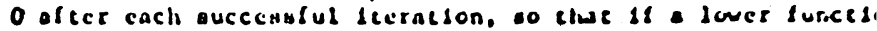


value is found after a restart, then a new attempt w111 be made to compute a covariance matrix.

IV(D)........ IV(27) is the starting subscript in $V$ of the current scale vector $D$ (are $V(D O)$ in 57 ).

IV(C)....... IV(28) is the starting subscript in $V$ of the current gradient vector $B=J(X) T_{R}(X)$.

IV(IFCAL.L)... IV(6) Is the number of calls so far made on CALCR (1.e., the number of function evaluations, including those used in computing covariance matrices).

IV (NFCOV).... IV (40) is the number of calls made on CALCR when computing covarlance matrices.

IV (NGCALL)... IV(43) is the number of calls so far made on CALCJ (1.e., the number of gradient evaluations, including those used in computing covariance matrices).

IV (:GCOV) .... IV(41) is the number of calls made on CALCJ when comput1ng covariance matrices.

IV(NITER) .... IV (44) is the number of 1terations performed.

IV(R)....... IV(50) is the starting subscript in $V$ of the residual vector $R(X)$.

\section{V Values of Prinary Interest}

Many of the $V$ input components described here and in $\$ 17$ must 11 e wthin a certain range of values. If such a component falls outside the range Indicated below (and in 517) at the beginning of its description, then codule PARCHK w111 print an error message (unless IV(PRUNIT) = 0) and w11l force NL2SOL to return fmedlately with IV(1) $\geqslant 18$.

Frequent reference is made below to two quantities: MACHEP and the scale vector D. MACHEP is the unit roundoff for the floating point artithnetic being used - . see 514 . The scale vector $D$ is the diagonal of the (diagonal) scale matrix $D_{k}$ discussed $1 \mathrm{n} 555$ and 7 of [1]; this scale matrix 18 denoted by $\mathrm{diag}_{\text {(D) }}$ below.

$\checkmark$ Input Values of Primary Interest (Supp11ed by DFAULI)

$\nabla(\operatorname{CONCR}) \ldots \nabla(29) \in[0,1]$ Is the cosine convergence tolerance. Let $J_{1}$

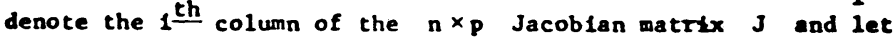

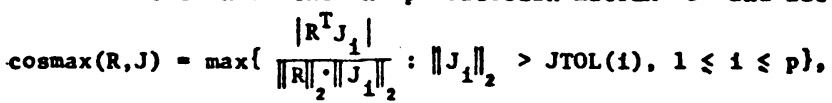

where JTOL is described with V(JTINIT) below. If NL2sol finde an $X$ giving $\operatorname{cosmax}(R(X), J(X)) \leq V(C C O N C R)$, then it returns wth IV (1) $=$ 4. Default $=\max \left(10^{-7}, 1000 \cdot\right.$ MACHEP $\}$

$\nabla(D E L T A 0) . . . \nabla(31) \in[$ [MCHEP, 1] helps plck the finite-difference steps 
used in computing $I 1$ when IV (COVREQ) $=1$ or 2 . The step used for component $X(i)$ is

$V(D E L T A O) \cdot \max \{|X(1)|, 1 / D(1)\} \cdot \operatorname{sign}(X(1))$,

where $D$ is the current scale vector. (If this step results

in CAl.CR nelting NF to 0 , then -0.5 timcs this etep to also

tried.) Default $=$ MACHEP ${ }^{(1 / 2)}$.

$\nabla(D F A C) \ldots . . V(32) \varepsilon[0,1]$ and $v(D 0)$ are used in updating the scale vector $D$ - see $V(D 0)$ below. Default $=0.6$.

$V(D I N I T) \ldots V(33)$, if nonnegative, is the value to which all components of the scale vector $D$ are intialized. Default $=0$.

$V(D L T F D C) \ldots V(34) \varepsilon[M A C H E P, 1]$ helps pick the step sizes used in computing II when IV(COVREQ) - -1 or -2 . For differences InvolvIng $X(1)$, the step first tried is $V(D L T F D C) \cdot \max \{|X(1)|, 1 / D(1)\}$.

(If this step is too large, 1.e., if CALCR sets NF to 0 when this step is first tried, then -0.5 times this step is also

tried.) Default $=$ MACHEP $^{(1 / 3)}$.

$\nabla$ (DLTFDJ)... $\nabla(35) \in[$ [MACHEP, 1] he1ps pick the step sizes that NL2SNo uses when computing its finite-difference approximation to the Jacobian matrix (see 58 ). For differences involving $X(1)$, the step first tried is V(DLTFDJ) - $\max \{|X(1)|, 1 / D(1)\}$. (If this step is too large, 1.e., if CALCR sets NF to 0 , then smaller steps are tried until the step size is shrunk below 1000 MACHEP.) Default - MACHEP $(1 / 2)$.

$V(D 0) \ldots . . . v(36)$ and $V(D F A C)$ are used in updating the scale vector $D$. If $V(D O)>0$, then at the start of each 1teration. $D(i)$ is set to $\max \left\{\left[\left\|J_{1}\right\|_{2}^{2}+\max \left\{S_{11}, 0\right\}\right]^{1 / 2}, V(D F A C) \cdot D(1), \operatorname{JTOL}(1), v(D 0)\right\}$, where $J_{1}$ is the 1 th column of the current Jacobian catrix, $S$ is the $S$ matrix of [1], and JTOL is the array described with $V$ (JTINIT) below. If $-1<V(D 0)<0$, then $D$ is set to the above values (after any initialization due to $V(D I N I T)$ ) on the first iteration and is not changed again. If $V(D O)=0$, then all components of $D$ are set to 1 (regardless of $V$ (DINIT)), which usually gives good performance on well-scaled probless. If $\nabla(D 0) \leqslant-1$, then $1 t$ is assumed that the caller has chosen $D$ and has stored it in $V$, starting at $v(96+2 N+P[7 P+41] / 2)$.

Default $=10^{-3}$.

$\nabla(J T I N I T) . . . V(38) \geqslant 0$. For $1 \leq 1 \leq P$, JTOL(1) is a tolerance used to decide whether the 1-th column of the Jacobian matrix should be considered to be zero. If V(JTINIT) > 0 , then all components of the JTOL, array are set to V(JTINIT), and if $V$ (JTINIT) $=0$, then $1 t$ is assumed that the caller has stored JTOL in V startIng at $\nabla(87)$. Default $=10^{-9}$.

$\nabla(\operatorname{unx} 0) \ldots \nabla(39)>0$ gives the aximu 2-norn allowed for the very first 
step that NL2SOL attempts. On problems where th1s step would otherulse be 1nordinately large, it is very useful to assign a codese value to $\mathrm{V}(\mathrm{L} u(x))$. Default -100.

$\nabla(R C O N C R) \ldots Y(40)>0$ is the residual converecnce tolerance. If

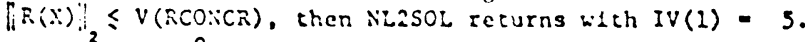
Default $-10^{-9}$.

$\nabla(V \cos C R)$... $V(42) \geqslant 0$ is the varlab1l1ty converence tolerance. If $\hat{\boldsymbol{t}}$ is the current liessian approximation, then the varlablitty of the current stcp $\Delta x$ is $V(V A R I A B)=\max \{1, N-P\} \cdot \Delta x^{\mathrm{T}} \hat{H} \Delta x /(2 F(X))$, where $2 \mathrm{~F}(\mathrm{X})$ is the current resldual sum of squarea. If $V(V A K I A B) \leqslant V(V C O N C R)$, then NL2SOL returng with IV(1) - 6 . Defauit $=10^{-4}$.

$\nabla($ ICONCR $) .. . v(2 \hat{\sigma}) \geqslant 0$ is the $x$ convergence tolcrance. If a step $\Delta x$ 1. trled that ylelds a nuch smaller function decrease than expected, and if $V(R E L D X) \leqslant V(X C O N C R)$, where $V(R E L D X)$ is the caxitiun relative change in any component of $X$ (whlch, for $x-x_{0}+\Delta x, 1$ s cosputed as

$$
\left.v(\text { PELD })-\operatorname{man}\left\{\frac{\left|x(1)-x_{0}(1)\right|}{|x(1)|+\left|x_{0}(1)\right|}: 1 \leq 1 \leq P\right\}\right],
$$

then NL2SOL retume with IV(1) - 3. Default - 1000-MACHEP.

\section{POupue Values of Prlmary Interest}

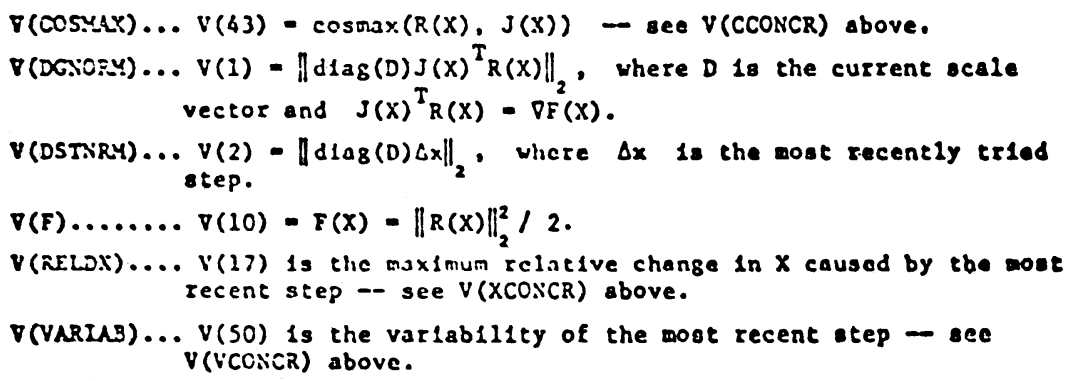

\section{Elnite-D1ffcrence Jacoblans -- NL2SNO}

Triose who do not wish to code a subroutine CALCJ for (analyt1cally) cospueing the dacuitan matrix fuy avold dolng so by calling NL2SNO Instead of Siz2SOL. :iL2S::0 coiputcs an approxlmate jocoblan matrix by forward differences (using a sicp slze determined by V(ULTFDJ) -- sce 57 ). The calling sequence for NL2S:io amounts to the one for NL2SOL with CALCJ osleted: CAI.L Ni.2SNO(N, P, X, CALCR, IV, V, UITAKM, URIANH, URPARMI) 
The paraweters for NZ2Sivo are the sase the corresponding ores for NL2SOL. One minor exception occurs with the handilng of $1 V^{\circ}\left(C O: R^{2} Q\right)$ : If IV (COVTRT) - I and IV (COVREQ) - 0, then NL2S:0 sets IY(CC:TEQ) - - 1; otherwisc NL2SNo sets IV(CO:RER) co-|IV(CO:RIQ)|. Thus Nizs::J uscs

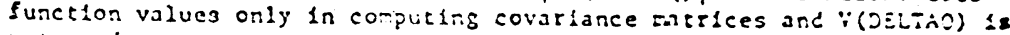
not used.

\section{Rectarting}

After any return with $3 \leq$ IV(1) 59 , 1t 10 possible to change soce of the $I V$ and $V$ input components (such as the corverence toiersices acd the lecration and function evaluation 11mits) and call :iL2SOL (or : again with IV(1) unchanged. Thly causes the algorlthm to be resured at the point where it was interrupted. (It la even possibje to save iV. $Y$. and $X$ and then restart in a eubsequent run.)

\section{Scaling}

Problems sometimes arfse which are poorly scaled in the sense that the varlous components of $X$ are expressed in wifely differti:z units. With the default cholce of the scale matrix $D$ (see $V(D O)$ and the tegt:ant:s of 57), the bchavior of NL2SOL. 1s largeiy inscrsielve to this klnd of foor ocaling. On well scaled problems, 1ts perforannce can ofien be izprosed

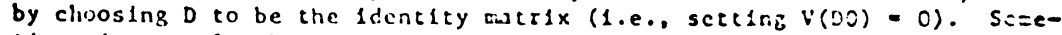
times $1 t$ may also be worthwhile to $f 1 \times D(1), 1 \leqslant 1 \leqslant P$, a: the 2-ros of tho 1-th column of the Inltial Jacobion oatrix (by ecting $V(D O)=-0.3$ ).

\section{MMAX: Limltins the E1rst Step Lengeh}

On some problems it is necessary to sive $V(L Y A X O)=V(39)$ a $s=a 11$ value to prevent a disastcrously large f1rst step, ore which $=:$ b: : ead to exponent overflow or argurents out of range to intrinsic fircticrs. Even $1 f$ no disaster occurs, if NL2SOL takes eany function evaluatioss on the flrot otep, then performance misht be laproved by a ejeh sialler (or In oome cases larger) value of $V(1 .: 1 \times 0)$.

Note that if $\Delta x$ is the very first step attespted, then $\| x_{2}$, racker than $\left\|d \operatorname{lag}_{(}(D) \Delta x_{2}\right\|_{2}$ is bounded above by $v(L A \lambda x O)$, because $1 t$ was feit that the caller mighe have a betzer ldea of hou $l_{i}^{A} x_{11}^{\prime \prime}$ brould be lieleec. As a result, $V(\operatorname{Lix} 0)$ is a scale-sensitive quantity.

\section{Local Solutions}

It can caslly happen that $81250 \mathrm{~L}$ only flinds a local $=1 n i=1 z e r$ of the oum-of-squares function $F(X)$ and that a differcit starting ouess veule cause a point to be found at which $F$ has a selil saslier value. Except

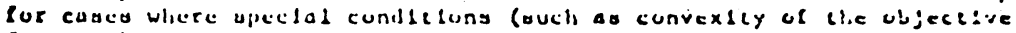
function) prevald. this shorceoming is shared by all olnigizacion algorlebas

\section{Printed Output}


PARCHK reforts any $V$ input components that are out of range and optionally lists any such components that have nondefault or changed valucs (on a fresh start or restart rcspectively). IISSRY does the remaining printing.

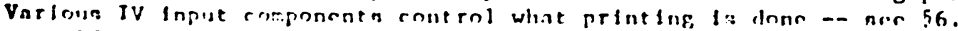

If IV(OLILEV) > 0 , then ITS:IRY produces an iteration sunumary which includes the following values: IT, the current teration number; NF, the number of function evaluations (calls on CALCR), excluding any extra ones needed for computing covariance matrices and, in the case of NI.2Sito, excluding the extra ones needed to compute finite-difference Jacobian matrices; $F$, the current function value (half the residual sum of squares); $D F$, the difference betheen the previous and current function values; CoSMAX, the current $\cos \operatorname{Tax}(R(X), J(Y))$-- see $V(C \operatorname{CON} C R)$ in 57; VAR, the current step var1abllity -- sce $V(V C N: i C R)$ in 57; MODEL, whlch tells whlch models were used in computing the current step IG = the Gauss-Newton model; $S=$ the augmented model; G-S means the Gauss-Newton model was tried first and $a$ switch was then made to the augmented model; S-G, G-S-G, and S-G-S have analogous meanlngs]; INiLDA, the current Levenberg-ilarquardt parameter $\lambda$ (which is nonnegative if the step $\Delta x$ just taken satisfles $\left[\hat{\mathrm{H}}+\lambda \cdot \operatorname{diag}(D)^{2}\right] \Delta x=-\nabla F(X-\Delta x)$, where $\hat{H}$ is the current Hessian approximation, and is negative if the special case discussed in [2] was detected); RELDX, the current value of V(RELDX) -- see V(XCONCR) In 57; G, the current value of $\|\nabla F(X)\|_{2}=\left\|J(X){ }^{T} R(X)\right\|_{2}$; SIZE, the sizing factor fust used in updating the $S$ matrix (see [1]); and $D \star S T E P$, the current value of $V$ (DSTNRM) - see 57. These summary lines are 118 characters long (Including the carriage control character). If IV (OUTLEV) $<0$, then 1 ines of maxinum length 69 (or 56 if IV (COVPRT) = 0) are generated, and the 1teration sumary includes only the first six 1tems described above (1.e., IT, NF, F, DF, COS.MiX, and VAR).

\section{Changlng Computers}

The IiL2SOL distribution tape contains both single- and double-precision versions of the $\mathrm{SL} 2 \mathrm{SOL}$ source code, so tt should be unnecessary to change precisions. (On computers having only 32 or 36 bits per REAL word, double precision of ten gives better performance.)

Only the functlons IMDCON and RYDCON contain machine-dependent constants. To change from one computer to another, 1t should suffice to change the DATA staterents in these functions. The DATA statement in IIDCON sets MDCON(1) to the output unit number that DFAULT supplies to IV (PRLNiT). The machine-dependent DATA statement in R:DCON provides three values: BIG, ETA, and MACHEP. BIG is the largest floating-point number such that a FORTRA: prograa can compute SQRT $(0.999 \star B I G) \star \star 2$ [1.e., DSQRT $(0.999 D 0 \star B I G) \star \star 2$ In DOCBLE PRECISION] without overflowing. Similarly, ETA is the smallest. floating-point number such that SQRT $(1.001 *$ ETA $) \star \star 2$ [or DSQRT $(1.001 D 0 \star E T A) \star \star 2$ respectively] does not underflow. MACHEP is the unit roundof $f$, 1.e., the smallest floating-polnt number such that 1 + MACHEP ylelds a stored floating point number greater than 1 and 1 - MACHEP ylelds a stored number less than 1. (Some computers feature reglsters that carry wore bits than can be stored; MACHEP should only reflect the accuracy of numbers that can be etored.) 
The test program supplied on the NL2SOL distribution tape places the further restriction on BIG and ETA that EXP(1.999*ALUG (SQRT (0.999*BIG))) and $\operatorname{EXP}(1.999 * \Lambda L O G(\operatorname{SQRT}(1.001 * \operatorname{ETA})))$ (DEXP $(1.999 D 0 \star D L O G(D S Q R T(0.99900 \star B I G)))$

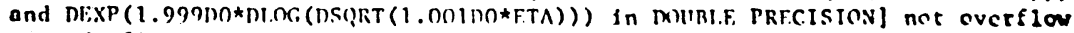
or underflow. DATA statements giving sultable values for BIC, ETA, and MACHEP for a variety of computers appear as comments in RYDCON.

Intrinsic functions are explicitly declared in the NL2SOL source code. On certain computers (e.g. Univac), it may be necessary to comment out these declarations. So that this may be done automatically by a simple program, such declarations are preceded by a comment having $\mathrm{C} /+$ in columas 1-3 and blanks in columns 4-72 and are followed by a coument having $\mathrm{C} /$ In columns 1 and 2 and blanks in columns 3-72.

\section{Using Reverse Communication -- NL2ITR}

Instead of writing subroutines CALCR and CALCJ to compute the res1dual vector $R(X)$ and Jacobian matr1X $J(X)$, one can call NL.2ITR and provide $R$ and $J$ by reverse communication. The caliling sequence is:

CALL NL2ITR(D, IV, J, N, NN, P, R, V, X)

Parameters IV, N, $P, V$, and $X$ are the same as the corresponding parameters to NL2SOL, with the following exceptions: $V$ need only contain $96+2 \mathrm{~N}+\mathrm{P}[7 \mathrm{P}+41] / 2$ elements, since the storage that NL2SOL and NL2SNO allocate for $D, J$, and $R$ at the end of $V$ is not needed; and components IV (D), IV(J), and IV(R) are not referenced. $D$ is the scale vector (dimengloned $D(P))$. NN is the (integer) lead dimension for the $J$ array, which is dimensioned $\mathrm{J}(\mathrm{NN}, \mathrm{P})$; $\mathrm{NN}$ must satisfy $\mathrm{NN} \geq \mathrm{N}$.

When NL2ITR is first called (with IV(1) $=0$ or 10), J must have been set to $J(X), R$ to $R(X)$. When NL2ITR wants $R$ to be evaluated at a new $X$, it returns with $I V(1)=1$; the caller should then set $R$ to $R(X)$ (unless $X$ is out of range, in which case the caller should set IV(TOOBIG), i.e., IV(2), to 1) and call NL2ITR again. Simllarly, when NL2ITR wants J to be evaluated at $X$, it returns with $I V(1)=2$, and the caller should then set $J$ to $J(X)$ and call NL2ITR again. (If $J$ cannot be evaluated at $X$, the caller may set IV(NFGCAL), 1.e., IV(7), to 0 ; this will cause NL2ITR to give the error return IV $(1)=13$.

\section{STOPX}

It 18 possible to arrange for NL2SOL (NL2SNO and NL2ITR) to be interrupted when used in an interactive environment. To do this, it is necessary to replace the logical function STOPX supplied with the NL2SOL package (which always returns. FALSE.) by a system-dependent STOPX that returns .TRUE. If and only if the "break" (1.e., "Interrupt") key has been pressed since the last call on STOPX. Once this $1 \mathrm{~s}$ done, Sh2SOL will return with IV $(1)=9$ when the "break" key is pressed before some other return has accurred. It 18 then possible to change sose of the IV and $V$ input components and restart -- see 59.

\section{Other $\nabla$ Input Values}

